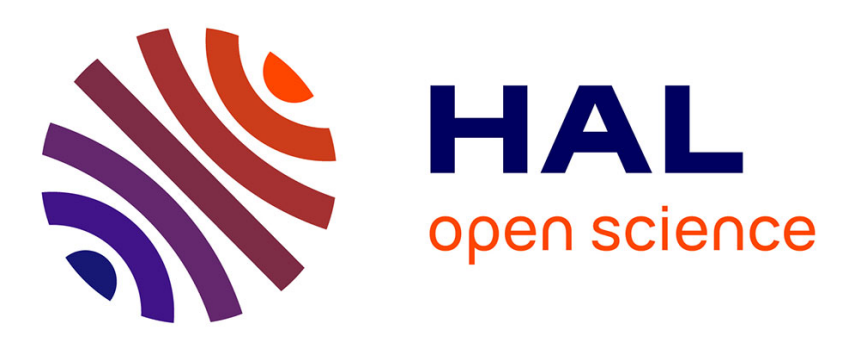

\title{
Quantifying Emerging Local Anthropogenic Emissions in the Arctic Region: The ACCESS Aircraft Campaign Experiment
}

Anke Roiger, Jennie L. Thomas, H. Schlager, Kathy S. Law, J. Kim, A. Schäfler, B. Weinzierl, F. Dahlkötter, I. Krisch, Louis Marelle, et al.

\section{To cite this version:}

Anke Roiger, Jennie L. Thomas, H. Schlager, Kathy S. Law, J. Kim, et al.. Quantifying Emerging Local Anthropogenic Emissions in the Arctic Region: The ACCESS Aircraft Campaign Experiment. Bulletin of the American Meteorological Society, 2015, 906 (3), pp.441-460. 10.1175/BAMS-D-1300169.1 . hal-01054384

\author{
HAL Id: hal-01054384 \\ https://hal.science/hal-01054384
}

Submitted on 7 Nov 2020

HAL is a multi-disciplinary open access archive for the deposit and dissemination of scientific research documents, whether they are published or not. The documents may come from teaching and research institutions in France or abroad, or from public or private research centers.
L'archive ouverte pluridisciplinaire HAL, est destinée au dépôt et à la diffusion de documents scientifiques de niveau recherche, publiés ou non, émanant des établissements d'enseignement et de recherche français ou étrangers, des laboratoires publics ou privés. 


\section{QUANTIFYING EMERGING LOCAL ANTHROPOGENIC EMISSIONS IN THE ARCTIC REGION The ACCESS Aircraft Campaign Experiment}

by A. Roiger, J.-L. Thomas, H. Schlager, K. S. Law, J. Kim, A. Schäfler, B. Weinzierl, F. Dahlkötter, I. Krisch, L. Marelle, A. Minikin, J.-C. Raut, A. Reiter, M. Rose, M. Scheibe, P. Stock, R. Baumann, I. Bouarar, C. Clerbaux, M. George, T. Onishi, and J. Flemming

The European Arctic Climate Change, Economy, and Society (ACCESS) aircraft campaign focused on quantifying emissions from shipping and oil/gas extraction and on pollution transported from midlatitudes into the Arctic.

View from the Falcon of shipping and hydrocarbon extraction activities in the Norwegian Sea during the ACCESS aircraft campaign (photo credit: S. Grillenbeck, DLR). he impact of Arctic industrialization, which is increasingly possible owing to reductions in sea ice, on local air quality, and on climate is not well understood (e.g., Corbett et al. 2010; Peters et al. 2011; Ødemark et al. 2012; Dalsøren et al. 2013). This article describes the Arctic Climate Change, Economy, and Society (ACCESS) aircraft campaign, which aimed to study emissions from human activities such as oil and gas extraction and shipping within the context of other pollution sources that impact the region. The campaign utilized the Falcon 20 aircraft from the Deutsches Zentrum für Luft- und Raumfahrt (DLR) that was equipped with atmospheric trace gas and aerosol instrumentation. The Falcon was based in Andenes, northern Norway $\left(69.29^{\circ} \mathrm{N}, 16.14^{\circ} \mathrm{E}\right)$, from 9 to 27 July 2012. Here, we present an overview of the ACCESS campaign measurements, model forecasts used for flight planning, and highlight first scientific results.

Although the Arctic is located far away from midlatitude pollution sources, air pollution is pervasive in the Arctic. During late winter and spring, Arctic pollution levels increase because the polar front reaches lower 
latitudes, allowing anthropogenic emissions from, for example, Eurasia to be more frequently transported into the region (e.g., Stohl 2006). In addition, pollution removal processes occur more slowly (e.g., Barrie 1986; Law and Stohl 2007; Quinn et al. 2007). Later in spring and summer, boreal and agricultural fires in Alaska, Canada, and Siberia impact the composition of the Arctic atmosphere (e.g., Warneke et al. 2009; Jacob et al. 2010; Singh et al. 2010; Brock et al. 2011; Thomas et al. 2013; Law et al. 2014). While local sources of emissions in the Arctic are rather small at present, there are several exceptions-for example, high sulfur emissions originating from the Kola Peninsula and Norilsk (Siberia) (Virkkula et al. 1998; Prank et al. 2010; Walter et al. 2012; Bauduin et al. 2014) as well as significant flaring emissions of black carbon (BC) related to oil and gas extraction in northern Russia (Stohl et al. 2013). However, these sources are poorly quantified (Prank et al. 2010; Walter et al. 2012; Stohl et al. 2013).

The impact of local emissions on Arctic tropospheric composition is not only limited to increasing the levels of air pollution but is also tied to climate

AfFiliations: RoIger, SCHLAger, Kim, SCHÄFler, DahlKötter, * Krisch, ${ }^{+}$Minikin," Reiter, Rose, Scheibe, Stock, and BaumannDeutsches Zentrum für Luft- und Raumfahrt (DLR), Institut für Physik der Atmosphäre, Oberpfaffenhofen, Germany; Thomas, Law, Marelle, Raut, Bouarar,@ Clerbaux, George, and ONISHI-Sorbonne Universités, UPMC Univ. Paris 06; Université Versailles St-Quentin; CNRS/INSU, LATMOS-IPSL, Paris, France; WEINZIERL-Deutsches Zentrum für Luft- und Raumfahrt (DLR), Institut für Physik der Atmosphäre, Oberpfaffenhofen, and Ludwig-Maximilians-Universität, Meteorologisches Institut, Munich, Germany; Flemming-European Centre for MediumRange Weather Forecasts, Reading, United Kingdom * CURRENT AFFILIATION: TSI GmbH, Aachen, Germany + CURRENT AFFILIATION: Institute of Energy and Climate Research: Stratosphere (IEK-7), Forschungszentrum Jülich, Jülich, Germany

\# CURRENT AFFILIATION: Deutsches Zentrum für Luft- und Raumfahrt, Flugexperimente, Oberpfaffenhofen, Germany @ CURRENT AFFILIATION: Max Planck Institute for Meteorology, Hamburg, Germany CORRESPONDING AUTHORS: Anke Roiger, DLR German Aerospace Center, Oberpfaffenhofen, Münchener Straße 20, 82234 Weßling, Germany; Jennie L. Thomas, LATMOS-UPMC, 4 place Jussieu, 75252 Paris CEDEX 05, France

E-mail: anke.roiger@dlr.de; jennie.thomas@latmos.ipsl.fr

The abstract for this article can be found in this issue, following the table of contents.

DOI:10.1175/BAMS-D-13-00169.1

A supplement to this article is available online (I0.II75/BAMS-D-I3-00169.2) In final form 16 July 2014

(C)2015 American Meteorological Society (e.g., Dalsøren et al. 2013; Ødemark et al. 2012). For example, $\mathrm{BC}$ impacts Arctic climate both in the atmosphere and upon being deposited onto ice and snow (e.g., Flanner et al. 2007; Bond et al. 2013). It is well known that climate change is proceeding much faster in the Arctic than on global average (Stocker et al. 2014). One open question is to what extent shortlived climate forcers, especially ozone and $\mathrm{BC}$ aerosols (Law and Stohl 2007; Quinn et al. 2008), contribute to climate change in this unique region, which is characterized by a high surface albedo, long periods of sunlight (darkness) in summer (winter), and polar boundary layer dynamics.

As a result of the significant reduction in Arctic sea ice, the region is opening for new human activities, including transit shipping and resource extraction. Specifically, the Arctic region is estimated to contain $30 \%$ and $13 \%$ of the world's untapped gas and oil reserves, respectively (Gautier et al. 2009). Oil and gas installations emit a broad mixture of gases (e.g., $\mathrm{NO}_{x}$, $\mathrm{SO}_{2}, \mathrm{VOCs}, \mathrm{CH}_{4}$ ) and aerosols including $\mathrm{BC}$ (e.g., Peters et al. 2011; Karion et al. 2013; Stohl et al. 2013; Pétron et al. 2014). Emissions during the extraction process occur because of power generation, burning natural gas and diesel as fuel, as well as from venting/ flaring activities (e.g., Jaffe et al. 1995; Peters et al. 2011; Stohl et al. 2013). The present impact of Arctic oil and gas extraction on air pollution and regional climate is discussed in a recent model study by Ødemark et al. (2012), which uses an emission inventory developed specifically for petroleum activities in the Arctic (Peters et al. 2011). According to their study, current Arctic oil and gas extraction emissions are responsible for regional net radiative forcing (RF) of approximately $20 \mathrm{~mW} \mathrm{~m}^{-2}$, mainly owing to emitted BC deposited on snow. However, models rely on a description of both emissions and chemical and aerosol processes (including BC) and it is well known that models have difficulties to accurately simulate pollutant concentrations in the Arctic region (e.g., Shindell et al. 2008; Lee et al. 2013; Schwarz et al. 2013). Shortcomings in modeled aerosol distributions can be partly attributed to incorrect treatment of scavenging processes in the models (e.g., Bourgeois and Bey 2011; Browse et al. 2012; Liu et al. 2012). However, Stohl et al. (2013) recently demonstrated that shortcomings in emission inventories, especially the absence of flaring emissions (originating from petroleum extraction and production processes in Russia), are also responsible for incorrect representation of $\mathrm{BC}$ in the Arctic. These uncertainties underline the need for the evaluation of current knowledge of Arctic oil and gas extraction emissions. Currently, 
the only observations reported in the literature are based on measurements of onshore oil extraction facilities in Prudhoe Bay, Alaska (Jaffe et al. 1995; Brooks et al. 1997; Brock et al. 2011).

A second important and increasing Arctic industrial activity includes both local (fishing, passenger, and local supply vessels) and transit shipping (bulk carriers and tanker ships) (e.g., Corbett et al. 2010; Peters et al. 2011). Arctic shipping routes that transit the Arctic are of high economic interest because of the shorter travel distances and fuel cost savings. For example, the route from Rotterdam to Yokohama is $40 \%$ shorter via the Northern Sea Route (a shipping lane along the Russian Arctic coast from Murmansk to the Bering Strait connecting Europe and Asia) compared to the distance through the Suez Canal (Liu and Kronbak 2010). Arctic shipping routes may reduce total ship emissions owing to shorter distances, which has positive effects on the impact of long-lived (i.e., well mixed) pollutants such as $\mathrm{CO}_{2}$. However, short-lived climate forcers such as BC and tropospheric ozone, directly emitted or formed in the Arctic, may have negative impacts on the regional pollution and climate (Sand et al. 2013; Schwarz et al. 2013; Stohl et al. 2013). The present and future impact of Arctic shipping on air pollution and regional climate has been discussed in recent model studies by Ødemark et al. (2012) and Dalsøren et al. (2013). The current net radiative forcing of Arctic shipping was found to be slightly negative $\left(\sim-20 \mathrm{~mW} \mathrm{~m}^{-2}\right)$, mainly because of cooling due to sulfate aerosols (Ødemark et al. 2012). However, expected International Maritime Organization (IMO) regulations on sulfur oxides $\left(\mathrm{SO}_{x}\right)$ emissions together with positive contributions from ozone and $\mathrm{BC}$ were suggested to turn the effect of shipping emissions into a net warming in 2030 (Dalsøren et al. 2013). It is important to note that shipping through the Arctic is not straightforward because both fuel savings and navigational risk are dependent on sea ice cover. In-Arctic shipping activities are projected to increase also because of resource extraction, fishing, and tourism. It has already been demonstrated by Eckhardt et al. (2013) that tourist ships increase $\mathrm{SO}_{2}$, ozone, and $\mathrm{BC}$ concentrations observed in Spitsbergen (an Arctic tourism destination) in summer.
There are large uncertainties both in quantity and composition of emissions from ships and oil and gas extraction activities based on measurements, especially in the Arctic. Knowledge of emissions and their atmospheric processing however is the basis for predicting current and future Arctic tropospheric composition. Therefore, improving and validating these emissions by characterizing type and amount of emissions from local Arctic pollution sources is essential. However, these emissions have to be considered in the context of other ongoing Arctic pollution sources and pollution transported into the Arctic region from both anthropogenic and biomass burning sources.

THE ACCESS AIRCRAFT CAMPAIGN. Scientific objectives and flight overview. The ACCESS campaign was conducted within the framework of the EU project ACCESS (www.access-eu.org), which focuses on the impact of Arctic climate change including human activities in the Arctic. The main objective of the ACCESS aircraft experiment and related model studies is to improve knowledge on the impact of Arctic industrialization, including shipping and hydrocarbon activities, on Arctic air pollution levels. During the ACCESS aircraft campaign 14 flights were performed, of which 9 flights were

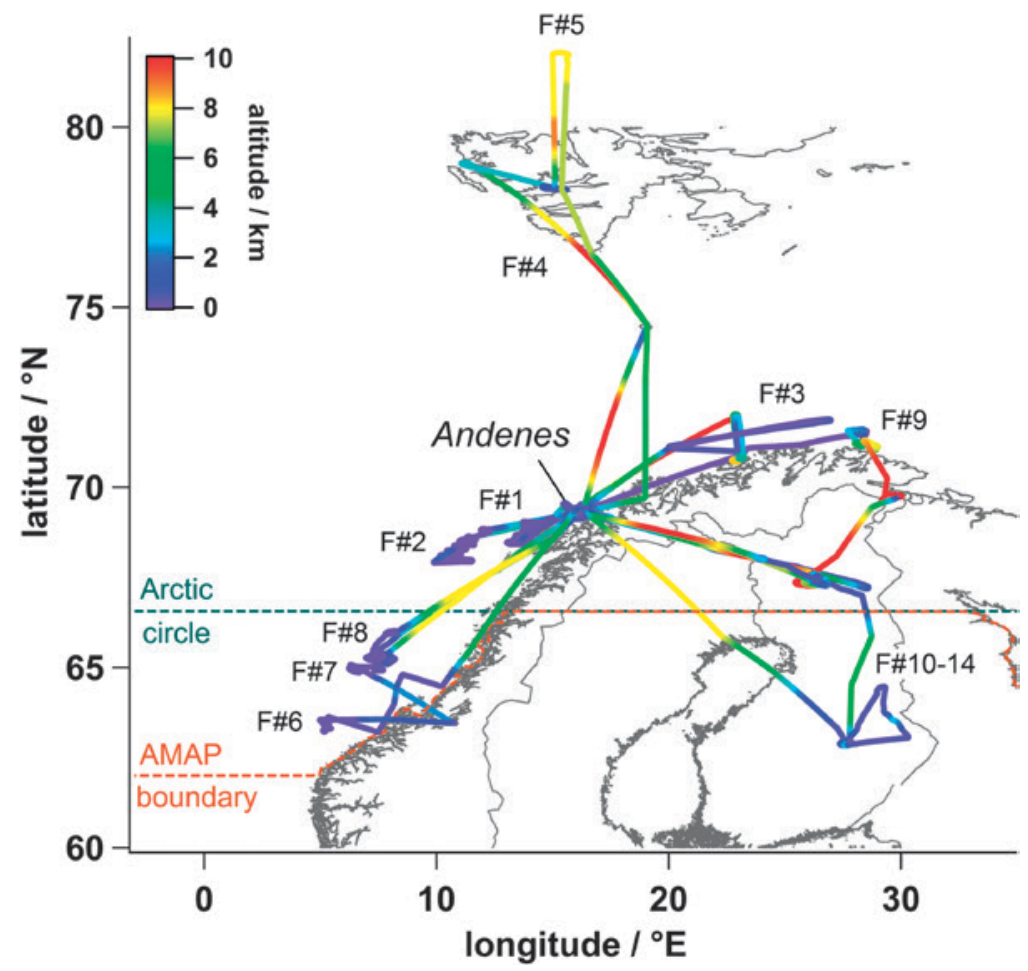

FIG. I. All Falcon flight tracks for the 14 ACCESS missions. The Falcon aircraft was based in Andenes (69.29 $\left.\mathrm{N}, 16.14^{\circ} \mathrm{E}\right)$. Flight altitudes are indicated by the color scale. The AMAP region (orange) and the Arctic Circle (turquoise) are also indicated. 


\begin{tabular}{|l|l|l|}
\hline \multicolumn{3}{|l|}{ TABLE I. Date and scientific objectives of all ACCESS missions. } \\
\hline Flight No. & Date & Scientific objective \\
\hline FI & II Jul 2012 & Single ship plume studies (Wilson Leer, Costa Deliziosa) \\
\hline F2 & I2 Jul 2012 & Single ship plume study (Wilson Nanjing) \\
\hline F3 & I3 Jul 2012 & Probing of Kola Peninsula emissions \\
\hline F4 and F5 & I7 Jul 2012 & Siberian biomass burning plume sampling \\
\hline F6 & 19 Jul 2012 & Ship emissions sampling \\
\hline F7 & 19 Jul 2012 & Sampling of oil and gas facility emissions in the Norwegian Sea \\
\hline F8 & 20 Jul 2012 & Probing of emissions from the Heidrun installation \\
\hline F9 & 25 Jul 2012 & Sampling of fresh ship emissions including fishing vessels \\
\hline Fl0-14 & $16,22,25$ Jul 2012 & Finland survey flights \\
\hline
\end{tabular}

\begin{tabular}{|c|c|c|}
\hline \multicolumn{3}{|l|}{ Falcon airborne measurements } \\
\hline Species or parameters & Method & Reference \\
\hline $\mathrm{CO}$ & VUV fluorescence & Gerbig et al. (1999) \\
\hline $\mathrm{O}_{3}$ & UV absorption & Baehr et al. (2003) \\
\hline $\mathrm{NO}, \mathrm{NO}_{2}$ & $\begin{array}{l}\text { Chemiluminescence }(\mathrm{CL}), \\
\text { photolytic converter }\end{array}$ & Ziereis et al. (2004), Pollack et al. (2010) \\
\hline $\mathrm{SO}_{2}, \mathrm{HNO}_{3}$ & CI-ITMS & Speidel et al. (2007), Roiger et al. (20l lb) \\
\hline $\begin{array}{l}\text { Aerosol number concentration and } \\
\text { size distribution }\end{array}$ & $\begin{array}{l}\text { CPC, OPC, UHSAS-A, PCASP, } \\
\text { FSSP-100 }\end{array}$ & $\begin{array}{l}\text { Stein et al. (2001), Heim et al. (2008), Cai et } \\
\text { al. (2008), Liu et al. (1992), Dye and Baum- } \\
\text { gardner (1984) }\end{array}$ \\
\hline $\begin{array}{l}\text { Absorbing aerosols, refractory black } \\
\text { carbon* mass and number concentrations, } \\
\text { size distribution, and coating thickness of } \\
\text { single refractory black carbon particles }\end{array}$ & $3 \lambda$-PSAP, SP2 & Virkkula et al. (2005), Schwarz et al. (2006) \\
\hline
\end{tabular}

\begin{tabular}{|c|c|c|}
\hline \multicolumn{3}{|c|}{ Satellite measurements } \\
\hline Species & Instrument & Reference \\
\hline $\mathrm{CO}$ & IASI FORLI-CO & George et al. (2009), Hurtmans et al. (20l2) \\
\hline
\end{tabular}

\section{Model forecasts}

\begin{tabular}{|l|l|l|}
\hline Tool & Description & Reference \\
\hline ECMWF forecast products & $\begin{array}{l}\text { Meteorological forecast provided } \\
\text { by the Mission Support System }\end{array}$ & Rautenhaus et al. (2012) \\
\hline Polar-WRF & Meteorological forecast & Hines and Bromwich (2008) \\
\hline $\begin{array}{l}\text { MACC (Monitoring Atmospheric } \\
\text { Composition and Climate) }\end{array}$ & $\begin{array}{l}\text { Global atmospheric chemistry and } \\
\text { CO tracer forecasts }\end{array}$ & Hollingsworth et al. (2008) \\
\hline WRF-Chem & $\begin{array}{l}\text { Regional meteorological and } \\
\text { chemical tracer forecasts }\end{array}$ & Grell et al. (2005), Fast et al. (2006) \\
\hline FLEXPART-WRF & Plume dispersion forecasts & Brioude et al. (2013) \\
\hline HYSPLIT & Plume dispersion forecasts & Draxler and Hess (1998) \\
\hline
\end{tabular}

* The terminology used in the scientific literature for black carbon is often ambiguous and different names are used based on specific particle properties and the associated measurement techniques (Petzold et al. 2013). Following the recommendations of Petzold et al. (2013), we use the more specific term "refractory black carbon ( $r B C)$ " in this manuscript when we refer to quantitative measurements of the $\mathrm{rBC}$ mass and number (or quantities inferred from rBC mass measurements) using the SP2. 
dedicated to studying Arctic air pollution. Figure 1 shows all ACCESS flight paths, noting that measurements were not possible in Russian airspace (east of $\left.30^{\circ} \mathrm{E}\right)$. Table 1 lists the specific scientific objective of each flight, which mainly focused on pollution off the Norwegian coast. All flights (with the exception of F10 and F11) were conducted within the Arctic Monitoring and Assessment Programme (AMAP) region, which is a definition of the Arctic region that incorporates elements of the Arctic Circle, political boundaries, and major geographic features (Murray 1998). In situ observations included measurements of carbon monoxide $(\mathrm{CO})$, ozone $\left(\mathrm{O}_{3}\right)$, nitrogen monoxide (NO), nitrogen dioxide $\left(\mathrm{NO}_{2}\right)$, nitric acid $\left(\mathrm{HNO}_{3}\right)$, sulfur dioxide $\left(\mathrm{SO}_{2}\right)$, aerosol number concentration and size distribution, and refractory black carbon ( $\mathrm{rBC}$ ) mass and number concentration, as well as a suite of meteorological observations. Most of the measurements were performed at a high temporal resolution of typically $1 \mathrm{~s}$ corresponding to a spatial resolution of about 100-200 m (depending on flight altitude). Table 2 gives an overview (more details are available in the online supplement: http:// dx.doi.org/I0.II75/BAMS-D-13-00169.2) of both the measurements and the tools used for flight planning (satellite and forecasts).

Most of the flights aimed to study pollution from low-altitude emission sources such as shipping and hydrocarbon extraction facilities. To study emissions from ships, several vessel types using different types

(a)

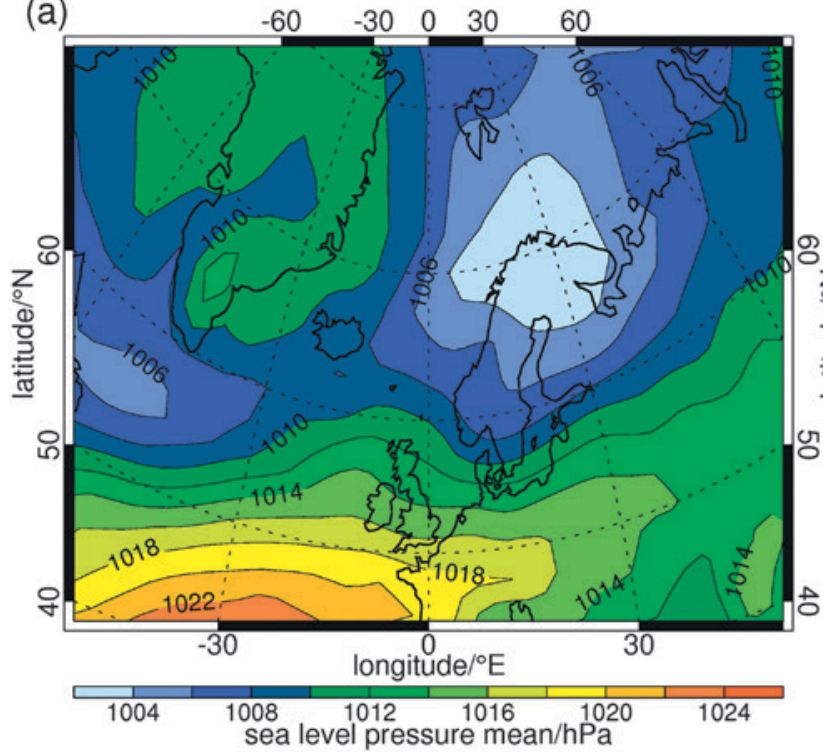

of fuel were targeted. For the analysis of emissions released by hydrocarbon extraction facilities, we focused on a number of oil and gas installations located in the Norwegian Sea. To evaluate the possible impact of future anthropogenic activities, the context of current pollution sources influencing the Arctic composition is important. Therefore, pollution from the smelting industrial complexes on the Kola Peninsula was also sampled after transport to the Barents Sea (west of Russian airspace) - a region reachable by the Falcon. Kola Peninsula industrial activities are known as a large source of anthropogenic sulfur $\left(\mathrm{SO}_{2}\right.$ and particulate sulfate) in the Arctic (e.g., Benkovitz et al. 1996; Virkkula et al. 1998; Prank et al. 2010; Kyrö et al. 2014). Also, during ACCESS we observed regular transport of Siberian and North American biomass burning emissions to northern Norway, providing us with the opportunity to study the chemical and aerosol composition in these plumes.

Meteorological context. The large-scale synoptic situation during the campaign was characterized by a persistent low pressure system that influenced large parts of northern Scandinavia, the Barents Sea, and the Norwegian Sea (Fig. 2a). During most days, the low over Scandinavia caused northerly winds along the coast of northern Norway. In contrast, weak high pressure dominated farther west over Greenland. To the south, a strong and persistent zonal jet stream was

(b)

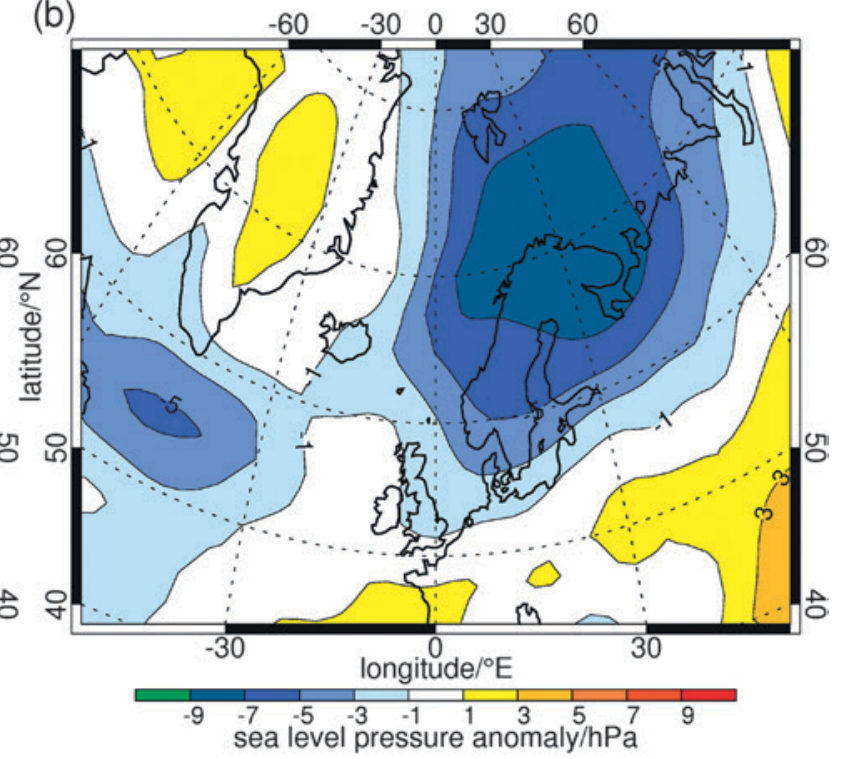

FIG. 2. (a) Sea level pressure mean composite (7-26 Jul 20I2) and (b) sea level pressure anomaly composite (with respect to 198I-2010 climatology) based on National Centers for Environmental Prediction-National Center for Atmospheric Research (NCEP-NCAR) reanalysis data (Kalnay et al. 1996). From the National Oceanic and Atmospheric Administration/Earth System Research Laboratory (NOAA/ESRL) Physical Sciences Division, Boulder, Colorado (www.esrl.noaa.gov/psd/). 

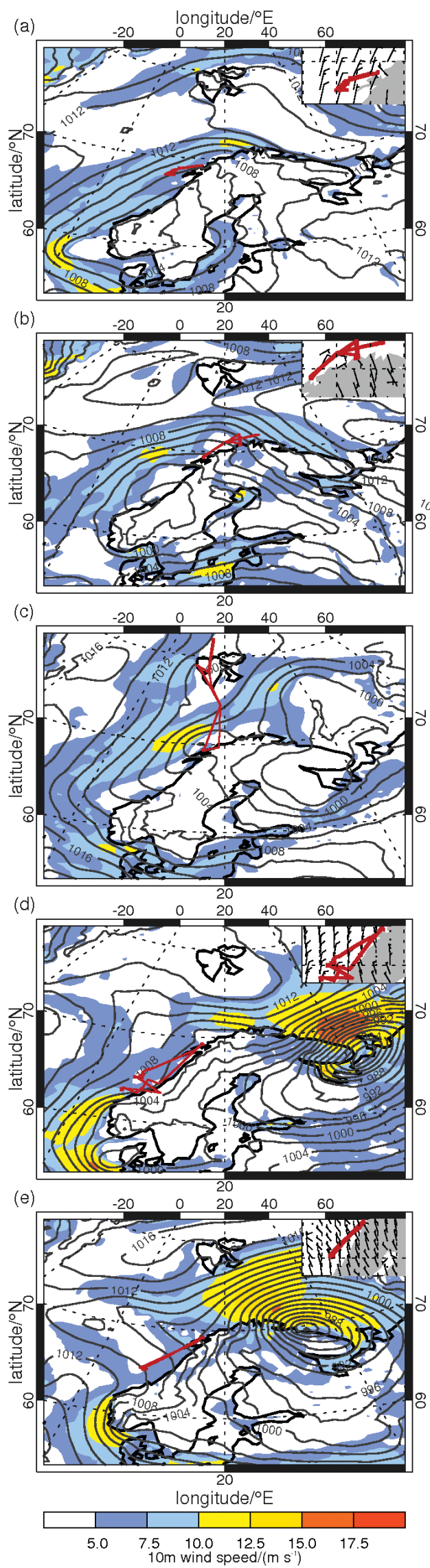

located over the North Atlantic. During the campaign period, the strength and position of the dominant low pressure system varied on a daily basis. It was encircled by a number of mesoscale cyclones resulting in a high frequency of episodes with low-level clouds and rain. Figure $2 \mathrm{~b}$ shows that the large-scale pressure pattern north of $60^{\circ} \mathrm{N}$ was anomalous with respect to the $30-\mathrm{yr}$ climatological mean, especially over northern Scandinavia where anomalously low pressures occurred related to the dominant and persistent low pressure system.

The mean sea level pressure, wind speed, and wind directions for five representative flight days are shown in Fig. 3. For example, Fig. 3a illustrates the northerly flow along the Norwegian coast south of Andenes, which was favorable for the ship-plume study conducted on 12 July. The southeasterly flow northeast of Andenes on 13 July allowed sampling of the Kola Peninsula plume over the Barents Sea (Fig. 3b). An intense low associated with clouds and rain was located off the coast of Andenes and prevented flights from 14 to 16 July because of high ground-level wind speeds. A pronounced northerly flow over Spitsbergen resulted in transport of biomass burning emissions from Siberian fires across the pole into the Arctic that was probed in detail by the Falcon aircraft on 17 July (Fig. 3c). The northerly and westerly low-level flow over the Norwegian Sea on 19 and 20 July (Figs. 3d and 3e), respectively, allowed undisturbed sampling of ship and oil and gas platform emissions without being impacted by any other land-based pollution.

ATMOSPHERIC PLUME DISPERSION. One challenge in studying the impact of localized emissions is to separate the contributions from chemical transformations and aerosol processing from those arising from dispersion processes in the atmosphere (e.g., Song et al. 2003). After release, the pollution plumes mix into the background atmosphere (surrounding air) and spread both vertically and horizontally, resulting in pronounced horizontal and vertical concentration gradients. Correct representation of dilution processes is needed in order to study both nonlinear chemistry (e.g., ozone production) and aerosol processing (e.g., coagulation) in freshly emitted plumes (e.g., Cariolle et al. 2009; Huszar et al. 2010; Vinken et al. 2011).

Atmospheric dispersion of source emissions close to the ground strongly depends on meteorological conditions (e.g., wind speed and direction, stability, and atmospheric turbulence). Therefore, to predict the location of plumes we used two different particle dispersion models [Flexible Particle dispersion model-WRF (FLEXPART-WRF; Brioude et al. 2013) and Hybrid Single-Particle Lagrangian Integrated Trajectory (HYSPLIT); see supplement] driven by meteorological

Fig. 3. ECMWF analysis of mean sea level pressure $(\mathrm{hPa}), 10 \mathrm{~m}$ wind speed at 1200 UTC (a) 12, (b) 13, (c) 17, (d) 19, and (e) 20 Jul 20I2. Small insets indicate low-level wind directions around the flight track (red; only given for flights which focused on lowaltitude emission sources). 

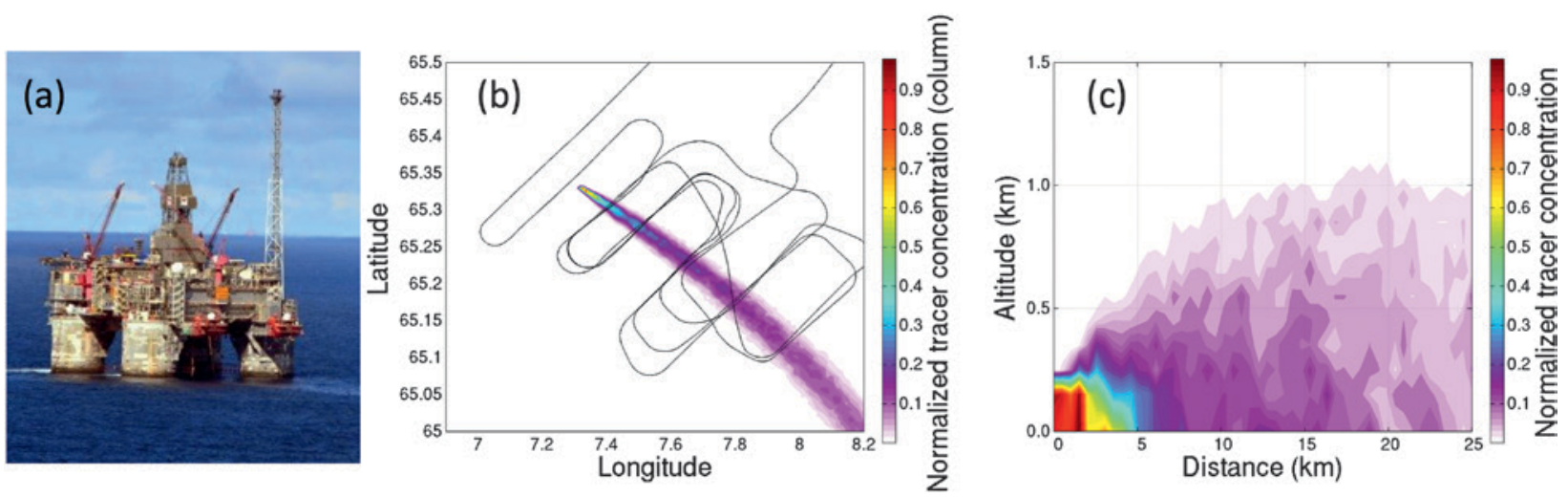

FIG. 4. Example of a plume dispersion forecast at 1430 UTC 20 Jul 2012 using FLEXPART-WRF that was used to plan the flight on 20 Jul 2012 focusing on the Heidrun platform. (a) Photo taken out of the Falcon cockpit (photo credit: S. Grillenbeck, DLR). (b) Forecast plume location and Falcon flight track. (c) Forecast vertical extent of the plume as a function of distance.

forecasts. The plume forecasts were important due to the numerous platforms and ships in the region (e.g., the Norwegian Sea) and helped to ensure clear separation between different plumes. An example is shown for the flight on 20 July 2012, which focused on the Heidrun production platform located in the Norwegian Sea (Fig. 4a). FLEXPART-WRF was run using the meteorology predicted as part of the WRF Chemistry (WRF-Chem) model forecast initialized at 1800 UTC 19 July 2012 by injecting a nonreactive tracer at the location of the Heidrun platform (plume injection for $24 \mathrm{~h}$ starting from 0000 UTC 20 July 2012). In Fig. $4 \mathrm{~b}$ both the forecast plume location (vertically integrated column concentration) and the flight track are shown. When studying a single plume, the objective was to characterize the plume using multiple plume crossings at different altitudes and distances. Furthermore, at least one crossing located upwind from the facility was necessary to separate the selected plume from any other pollution source. Figure $4 \mathrm{c}$ shows the predicted vertical extent of the plume as a function of the distance from the Heidrun platform. It shows a rapid vertical dispersion of the pollution plume in the boundary layer and indicates why it was important to characterize the plume using several flight legs at different altitudes. In this case, the plume was sampled using an S-shaped pattern that crossed the plume four to five times downwind of the platform, which was repeated at the altitudes 100,300 , and $480 \mathrm{~m}$. The plume sampled during this flight was also impacted by emissions from an oil tanker (Randgrid) located near the platform. This observation demonstrates that it is essential to not only understand the emissions from the platform itself but also to take emissions from the associated shipping traffic into account.

\section{EMERGING LOCAL EMISSION SOURCES.}

Emissions from offshore oil and gas extraction and exploration facilities. During the campaign two ACCESS flights were dedicated to studying the emissions from offshore oil and gas extraction facilities. In summer 2012, there were 13 active fields in the Norwegian Sea, compared with only one active installation in the Barents Sea (www.npd.com). Therefore, we focused our measurements on oil and gas facility emissions in the Norwegian Sea, which is located within the AMAP Arctic region (see inset Fig. 5). Measurements near platforms require low altitude flying and high visibility for safety $(>10 \mathrm{~km})$ with minimal cloud cover. The favorable meteorological conditions predominant on 19 July allowed the performance of a flight in the Norwegian Sea, which was aimed at surveying the area and measuring emissions from different types of facilities. During the flight, northerly/northeasterly winds (see Fig. 3d) and moderate wind speeds of 5-7 $\mathrm{m} \mathrm{s}^{-1}$ were observed. To support the interpretation of the measurements, the flight was performed in close collaboration with the Norwegian oil company Statoil (www.statoil.com), which confirmed normal operating conditions for most of the facilities during the flights. We observed enhancement in pollution downstream from all facilities (see Fig. 5; NO mixing ratios color coded along the flight track). In addition to emissions from oil platforms, ship pollution was also occasionally sampled in the vicinity of the facilities because of ship traffic in the region of the platforms (e.g., transport tankers).

A distinct pattern in the chemical and aerosol composition in plumes originating from different types of facilities was clearly observed (Kim et al. 2013). Briefly, an example of measurements for the 


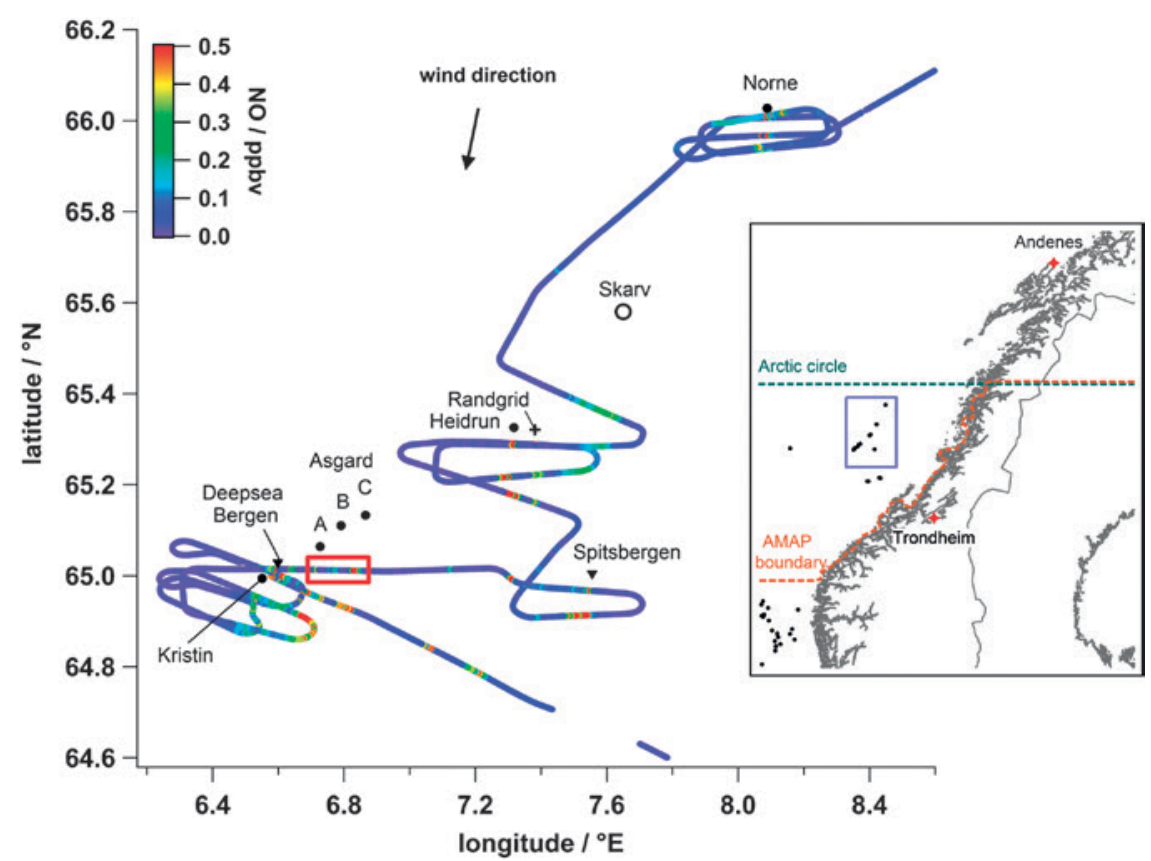

FIG. 5. Nitrogen oxide (NO) mixing ratios (indicated by the color of the flight track) measured during the ACCESS flight on 19 Jul 2012. The locations of all surface facilities are indicated. Probed Statoil facilities included the permanent platforms Kristin, Åsgard, Heidrun, and Norne (filled circles), the drillings rigs Deepsea Bergen and Transocean Spitsbergen (triangles), and the oil tanker Randgrid (cross). Also emissions from the British Petroleum (BP) installation Skarv was sampled, which in summer 2012 was under development (open circle). Measurements were made at altitudes of $120-250 \mathrm{~m}$ and horizontal distances to the installations ranged from 2 to $22 \mathrm{~km}$. The portion of the flight that focused on the Asgard facilities (time series presented in Fig. 6) is shown within the red box. The inset map indicates location of the measurement area off the Norwegian coast (blue rectangle) as well as the AMAP region (orange) and the Arctic Circle (turquoise).

Åsgard field (see red box in Fig. 5) is shown in Fig. 6. The Åsgard site consists of three single installations, including an oil and a gas production facility ( $̊$ sgard $\mathrm{A}$ and $\mathrm{B}$ ) as well as a condensate storage tanker (Åsgard C). The emissions released by the Åsgard A and $\mathrm{B}$ production facilities showed enhancements in total number of particles and NO, while enhancement in $\mathrm{SO}_{2}$ was not observed. Interestingly, despite the low concentrations of $\mathrm{SO}_{2}$, a significant increase in the nucleation mode particle fraction (up to $50 \%$ of total particle concentrations) was observed in fresh Åsgard $\mathrm{A}$ and $\mathrm{B}$ emissions (plume ages of approximately 20 and $35 \mathrm{~min}$, respectively). This suggests new particle formation in the plumes, probably owing to high levels of coemitted VOCs originating from gas venting. In contrast, the emissions from the Åsgard C tanker were characterized by high $\mathrm{SO}_{2}$ concentrations and a high fraction of nonvolatile particles $(>80 \%)$ together with enhanced $\mathrm{rBC}$ mass concentrations. The number concentration of nonvolatile particles (mostly BC, organic matter, and ash in plumes) was a factor of about 100 higher than the number concentration of $\mathrm{rBC}$ containing particles detected with the single particle soot photometer (SP2). This difference was already observed during earlier studies of fresh ship plumes (e.g., Buffaloe et al. 2014). The reason for this is that most of the BC particles emitted by the Åsgard C tanker were smaller than the lower detection limit of the SP2, which is $0.48 \mathrm{fg}$, corresponding to an equivalent $\mathrm{rBC}$ diameter of $80 \mathrm{~nm}$. The particle size distribution measured by the ultrahigh sensitivity aerosol spectrometer (UHSAS-A) in the Åsgard C plume is shown in Fig. 7 and is compared to that measured in the clean marine boundary layer air. These measurements indicate that there was a large enhancement in the particle number concentration in the plume for particles less than $170 \mathrm{~nm}$ in diameter with the modal diameter of the size distribution being smaller than the lower detection limit of both the SP2 and the UHSAS-A. The probed drilling rigs (Deepsea Bergen and Transocean Spitsbergen) released moderate levels of $\mathrm{SO}_{2}$ along with a high number of $\mathrm{rBC}$ containing particles (Kim et al. 2013), suggesting that exploration drilling may be a more important source of BC than production facilities.

Ship emissions. There are a number of publications on in situ measurements of emissions from various vessel types and under different conditions (Hobbs et al. 2000; Lack et al. 2009, 2011; Lack and Corbett 2012; Williams et al. 2009; Jonsson et al. 2011; Diesch et al. 2013; Cappa et al. 2014; Beecken et al. 2014). During ACCESS we generally focused on the smaller vessel types, which are expected to operate in the Arctic in the future. We sampled fresh emissions released by different types of ships, including cargo, passenger ships, and fishing vessels using different fuels including heavy fuel oil (HFO) and marine gas oil (MGO). 
MGO is more refined than HFO and has lower sulfur content. Table 3 lists most vessels we probed, including vessel types, dimensions, and engine type. It also shows ratios of observed emissions-namely, ratios of $\mathrm{SO}_{2}$ (which is dependent on fuel sulfur content) to $\mathrm{NO}_{x}$ (which is related to combustion temperatures) and the fraction of nonvolatile particles. The plumes were usually sampled very close to the ships to prevent any atmospheric processing. It is worth noting that sampling of emissions close to fishing boats was complicated by the large number of birds around the vessels and the resulting safety issue for the aircraft. As expected, the lowest $\mathrm{SO}_{2}$-to- $\mathrm{NO}_{x}$ ratio was observed for the ship running with MGO (Wilson Leer), while the highest ratio was found in the plume released by the largest vessel (Costa Deliziosa). The percentage of nonvolatile particles by number ranged between $50 \%$ and $79 \%$-similar to findings of Petzold et al. (2008) and Moldanová et al. (2013).

During ACCESS we also investigated the chemical and dynamical evolution of pollutants released by three different vessel types (small and midsize cargo ships, passenger vessels), similar to the studies of, for example, Song et al. (2003), Chen et al. (2005), and Petzold et al. (2008). On 12 July, the Wilson Nanjing, a midsize cargo ship running with HFO, traveled northward along the Norwegian coast. The northerly wind conditions on that day (Fig. 3a) resulted in the heading of the ship being into the wind, resulting in rapid dilution of the plume. Plume dispersion forecasts from the HYSPLIT model were used to plan of 80-5 I0 nm. this experiment and the Falcon flight was designed to cover the three-dimensional structure of the evolving plume, from the vicinity of the vessel up to a downwind distance of more than $70 \mathrm{~km}$. The flight was performed in close collaboration with the ship operator (Wilson Ship Management). On the day of the experiment, the captain reported his current position, vessel speed, and heading, which allowed the calculation of the approximate plume position at the time of the flight. HYSPLIT plume forecasts

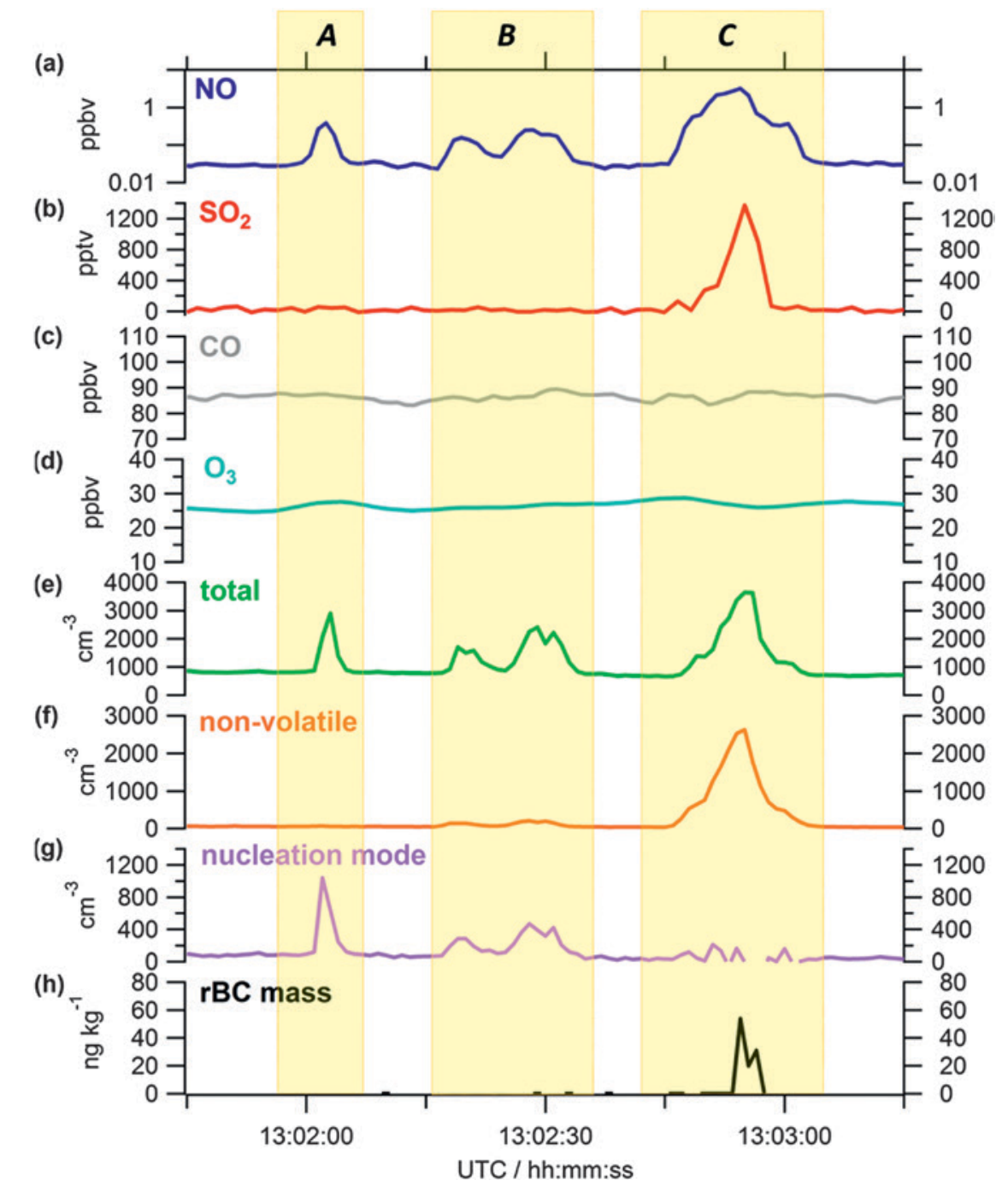

Fig. 6. (a)-(d) Trace gas, (e)-(g) particle number, and (h) rBC mass concentrations measured in the plumes emitted by three different facilities that make up the Åsgard site (see red box in Fig. 5): Åsgard A (oil production vessel), Åsgard B (gas production platform), and Åsgard C (storage tanker). Note that the Åsgard A platform was not fully operating at the time of our measurements (M. Gjaever, Statoil, 2012, personal communication). Distances to platforms during plume encounters were approximately $6,1 \mathrm{I}$, and $13 \mathrm{~km}$ for facilities $A, B$, and C, respectively. Please note that the $\mathrm{rBC}$ mass concentration refers to measurements of $r B C$ in the mass range between 0.48 and $125 \mathrm{fg}$, which corresponds to an equivalent diameter 
were performed using emission tracers released every minute along the planned ship track (Fig. 8a).

Figure $8 \mathrm{~b}$ shows the measured $\mathrm{NO}_{x}$ concentration along the flight path on 12 July 2012. At the beginning

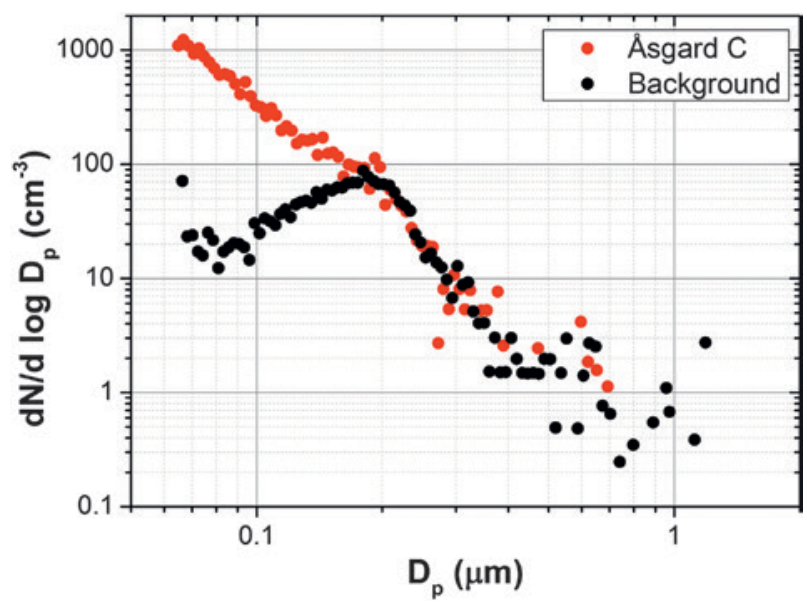

FIG. 7. Size distributions measured by UHSAS-A in the Asgard C plume (1302:39-1303:09 UTC) and in the clean marine boundary layer (1235:06-1238:09 UTC) on 19 Jul 2012 (flight data shown in Figs. 5 and 6). The background size distribution shows the cloud residue mode (Hoppel et al. 1986) at about $200 \mathrm{~nm}$, which is formed from cloud processing. The plume size distribution shows that the particle concentration is greatly enhanced for particles $<170 \mathrm{~nm}$. of the flight, the Falcon approached the vessel to search for the fresh plume, indicated by strong enhancements in gas and aerosol concentrations (as observed by the instrument operators onboard the Falcon). The plume was then sampled downstream during several passes, based on the positions as forecast by the HYSPLIT model in combination with real-time in situ measured wind direction. Communication between the pilots, the mission scientist, and the instrument operators ensured that the plume was encountered during each transect before the Falcon proceeded to the next flight leg. The slight gradient in observed $\mathrm{NO}_{x}$ mixing ratios toward the coast is due to other ships traveling in the measurement region. The maximum $\mathrm{NO}_{x}$ and total and nonvolatile particle concentrations measured during each plume transect are presented as a function of distance from the emission source in Fig. 8c. It shows that aerosol and $\mathrm{NO}_{\mathrm{x}}$ concentrations were still above background levels even about $1.5 \mathrm{~h}$ after emission.

\section{EMERGING ARCTIC INDUSTRIALIZA- TION IN CONTEXT OF CURRENT ARCTIC} POLLUTION. Kola Peninsula emissions. Smelting industrial complexes emit large amounts of $\mathrm{SO}_{2}$, an aerosol precursor, due to the presence of sulfur in metal ores. Most knowledge about $\mathrm{SO}_{2}$ emissions

TABLE 3. Summary of ship emission measurements.

\begin{tabular}{|c|c|c|c|c|c|c|}
\hline $\begin{array}{c}\text { Flight } \\
\text { No. }\end{array}$ & $\begin{array}{c}\text { Name of } \\
\text { vessel }\end{array}$ & $\begin{array}{l}\text { Vessel } \\
\text { type }\end{array}$ & $\begin{array}{l}\text { Gross tonnages } \\
\text { or dimensions }\end{array}$ & Engine type & $\begin{array}{c}\mathrm{SO}_{2} / \mathrm{NO}_{\mathrm{x}}^{\mathrm{a}} \\
\text { (No. of plume } \\
\text { samples) }\end{array}$ & $\begin{array}{c}\text { Fraction (by number) } \\
\text { of nonvolatile } \\
\text { particles }^{\text {a }} \text { (No. of } \\
\text { plume samples) }\end{array}$ \\
\hline $\mathrm{FI}$ & Costa Deliziosa & $\begin{array}{l}\text { Passenger } \\
\text { ship }\end{array}$ & 92,720 & $\begin{array}{l}\text { Medium speed } \\
\text { diesel engine }\end{array}$ & $0.57 \pm 0.14(7)$ & $0.79 \pm 0.11(7)$ \\
\hline F9 & $\begin{array}{c}\text { Mikhail } \\
\text { Strekalovski }\end{array}$ & Bulk carrier & 16,253 & $\begin{array}{l}\text { Slow speed } \\
\text { diesel engine }\end{array}$ & $0.44 \pm 0.11(2)$ & $0.50 \pm 0.07(2)$ \\
\hline F2 & Wilson Nanjing & Cargo ship & $6,118^{b}$ & $\begin{array}{c}\text { Medium speed } \\
\text { diesel engine }\end{array}$ & $0.47 \pm 0.12(6)$ & $0.65 \pm 0.09(5)$ \\
\hline $\mathrm{FI}$ & Wilson Leer & Cargo ship & $2,446^{c}$ & $\begin{array}{c}\text { Medium speed } \\
\text { diesel engine }\end{array}$ & $0.05 \pm 0.01(\mathrm{I})$ & $N / A^{d}$ \\
\hline F9 & Koralen & Fishing boat & $\mathrm{LxB}=49 \mathrm{~m} \times 9 \mathrm{~m}$ & Unknown & $0.13 \pm 0.03(2)$ & $0.75 \pm 0.11(4)$ \\
\hline F9 & Sorvik & Fishing boat & $\mathrm{LxB}^{\mathrm{e}}=15 \mathrm{~m} \times 6 \mathrm{~m}$ & $\begin{array}{l}\text { Medium speed } \\
\text { diesel engine }\end{array}$ & $0.15 \pm 0.04(\mathrm{I})$ & $0.69 \pm 0.10(I)$ \\
\hline
\end{tabular}

a The ratios of $\mathrm{SO}_{2}$ to $\mathrm{NO}_{x}$ and the fraction of nonvolatile particles were calculated using the integrated peak areas for each plume encounter. Uncertainties were calculated using the instrument uncertainties combined in quadrature.

${ }^{b}$ Fuel type: RMG380CST.

c Fuel type: marine gas oil (DMA), sulfur content 0.082 .

${ }^{d}$ The dilution system was switched off during this plume measurement and the total particle number concentrations exceeded the upper detection limit of the instrument.

${ }^{e} \mathrm{LxB}$ : length $\times$ beam (width at the widest point). 
from the Kola Peninsula is based on groundbased observations from stations located in Finland and Norway (e.g., Virkkula et al. 1998; Prank et al. 2010; Kyrö et al. 2014). Recently, using a combination of dispersion modeling with ground-based observations, Prank et al. (2010) showed that the emission rates of $\mathrm{SO}_{x}$ are strongly underestimated in the major European emission inventories. They concluded that the Kola Peninsula is still the largest source of $\mathrm{SO}_{x}$ in Northern Europe and the second largest (after the Norilsk industrial region) in northern Eurasia. Aircraft sampling of Kola Peninsula emissions is difficult because of the required permissions to operate in Russian airspace (e.g., Paris et al. 2008).

Meteorological forecasts showed that southeasterly wind conditions favored transport from the Kola Peninsula to the Barents Sea on 13 July (Fig. 3b), which is a region reachable by the Falcon, therefore allowing us to sample these emissions above ground level and at multiple altitudes. Accordingly, a flight route was planned using $\mathrm{SO}_{2}$ tracer forecasts from the WRF-Chem model (see supplement for more details), illustrated in Fig. 9a. Figure 9b shows a time series of $\mathrm{SO}_{2}$ mixing ratios during the most eastward part of the flight together with the aircraft altitude. Elevated $\mathrm{SO}_{2}$ concentrations varied from about 200 pptv up to more than 1 ppbv, while typical atmospheric background mixing ratios were in the range of a few tens of parts per trillion by volume. The time series of several trace gas and aerosol species during this period is shown in the electronic supplement (Figs. ES3 and ES4). Briefly, both $\mathrm{rBC}$ and other aerosols were enhanced in the boundary layer; however, the elevated aerosol concentrations did not always correlate with $\mathrm{SO}_{2}$. During the flight, we partially observed cloudy conditions, and European Centre for Medium-Range Weather Forecasts (ECMWF) forecasts showed that low clouds were predicted 1-2 days earlier in the region of the Kola Peninsula. Therefore, the plume is likely to have been impacted by wet removal of aerosols and cloud processing prior to measurement and thus requires chemical transport modeling (including full chemistry) to quantify these processes.

Pollution import to the Arctic from lower latitudes. In addition to local high-latitude emissions, imported pollution from lower latitudes (Europe, (a)

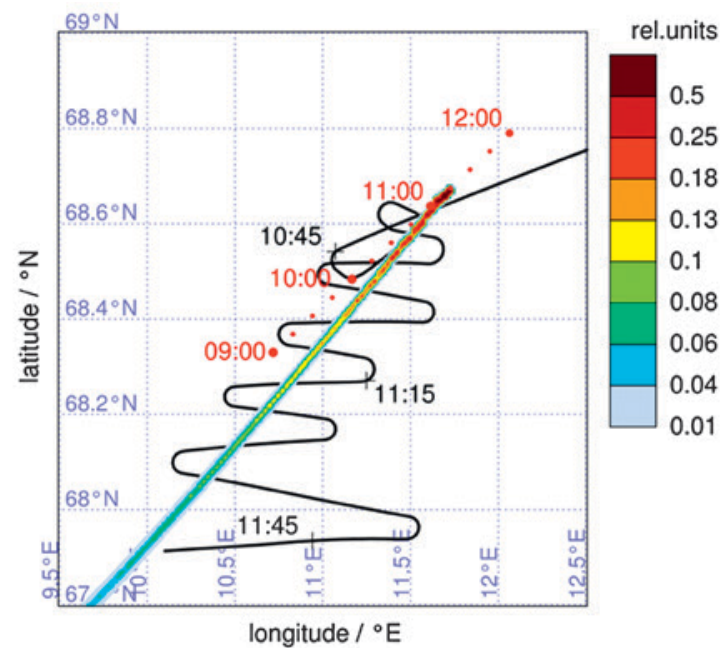

(b)

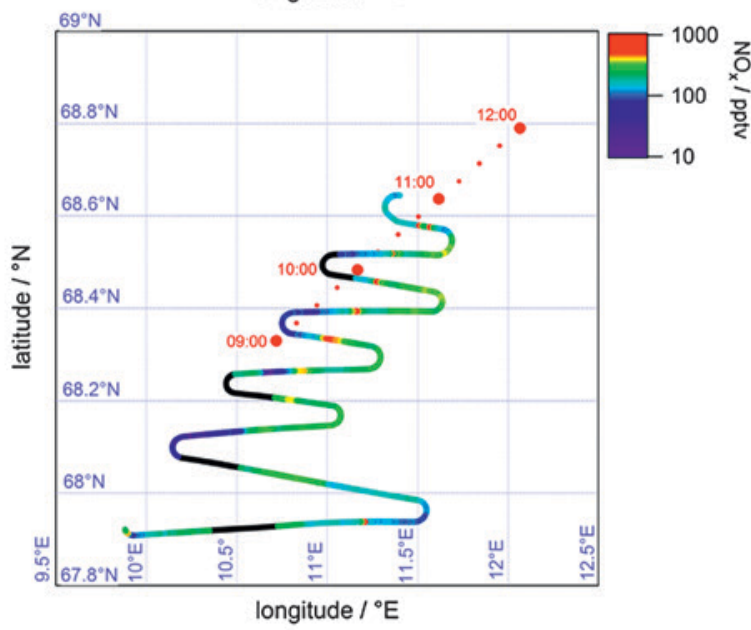

(c)

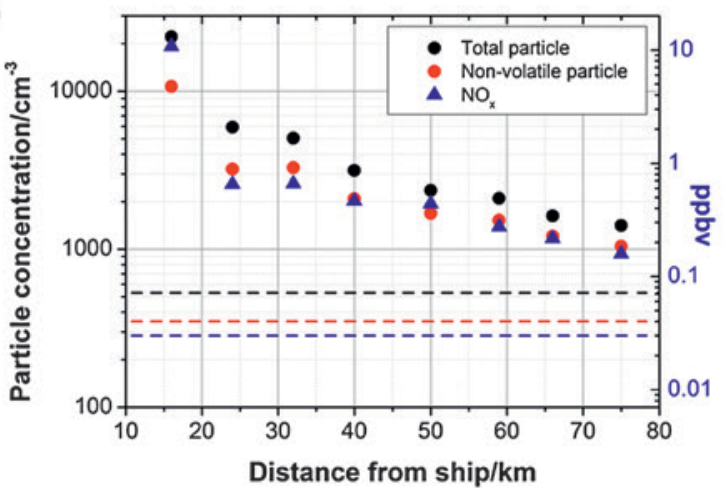

FIG. 8. (a) HYSPLIT forecast of the Wilson Nanjing plume location at the altitude of the aircraft measurements. HYSPLIT run was initialized using the ECMWF meteorology forecast (I200 UTC II Jul). (b) Flight track of the single plume study on 12 Jul ( 1050-II50 UTC), color coded by measured NO concentration. Black indicates missing data due to internal calibration periods. (c) Measured maximum concentrations of total particle number (black), nonvolatile particle number (red), and $\mathrm{NO}_{x}$ (blue) as a function of distance from the Wilson Nanjing. Instrument uncertainties are $15 \%$ for NO and $10 \%$ for total and nonvolatile particles. The dashed lines represent corresponding background concentrations. 
North America, and Asia) can strongly impact trace gas and aerosol concentrations in the Arctic (e.g., Law et al. 2014 and references therein). Recently, an increase of boreal wildfire activity and expansion of burned areas has been observed in North America and Siberia (e.g., Stocks et al. 1998; Kasischke and Turetsky 2006; Ponomarev 2013; Kelly et al. 2013). Siberia is one of the largest boreal fire regions and contributes to pollution transported to the Arctic. It is well known that fires emit large amounts of a number of trace gases including $\mathrm{CO}, \mathrm{CO}_{2}, \mathrm{CH}_{4}$, and hydrocarbons, as well as various smoke aerosols (e.g., Andreae and Merlet 2001) and that these emissions may be transported over hundreds to thousands of kilometers (e.g., Huntrieser et al. 2005; Petzold et al. 2007; Stohl et al. 2007;
Weinzierl et al. 2011; Dahlkötter et al. 2014). Summer 2012 in Siberia was one of the hottest on record, which resulted in extended forest fires that produced very high emissions rates of a number of trace species (Ponomarev 2013). One tracer of fire plumes is carbon monoxide (CO), which is an incomplete combustion product, and is also readily detected by satellites. We used Infrared Atmospheric Sounding Interferometer (IASI)-retrieved CO total columns, as well as global trace gas forecasts from the Monitoring Atmospheric Composition and Climate (MACC) to identify polluted air masses as they crossed the Arctic from Siberia to the campaign region in northern Norway-a transport pathway that was also documented during the Polar Study using Aircraft, Remote Sensing, Surface Measurements and Models, of Climate, Chemistry, Aerosols, and Transport (POLARCAT) campaign (Roiger et al. 2011a; Sodemann et al. 2011) and impacted vertical profiles downwind over Greenland (Law et al. 2014).

Specifically, a CO-rich air mass was identified in the satellite retrievals (see black arrows in Fig. 10) on 13 July, which during the following days was transported across the pole into the region of northern Norway. In addition, MACC forecasts of total $\mathrm{CO}$ and a Siberian biomass burning (BB) CO (tracer)predicted enhanced pollution north of Norway (Fig. 11) on 17 July 2012. Using these two tools, two flights were planned with a stopover in Spitsbergen in order to probe the vertical structure of the biomass burning plume in great detail, although it was clear from the MACC forecasts (Fig. 11) that the largest $\mathrm{CO}$ enhancements were out of the Falcon range. The Falcon transected BB pollution located between Andenes and Spitsbergen 

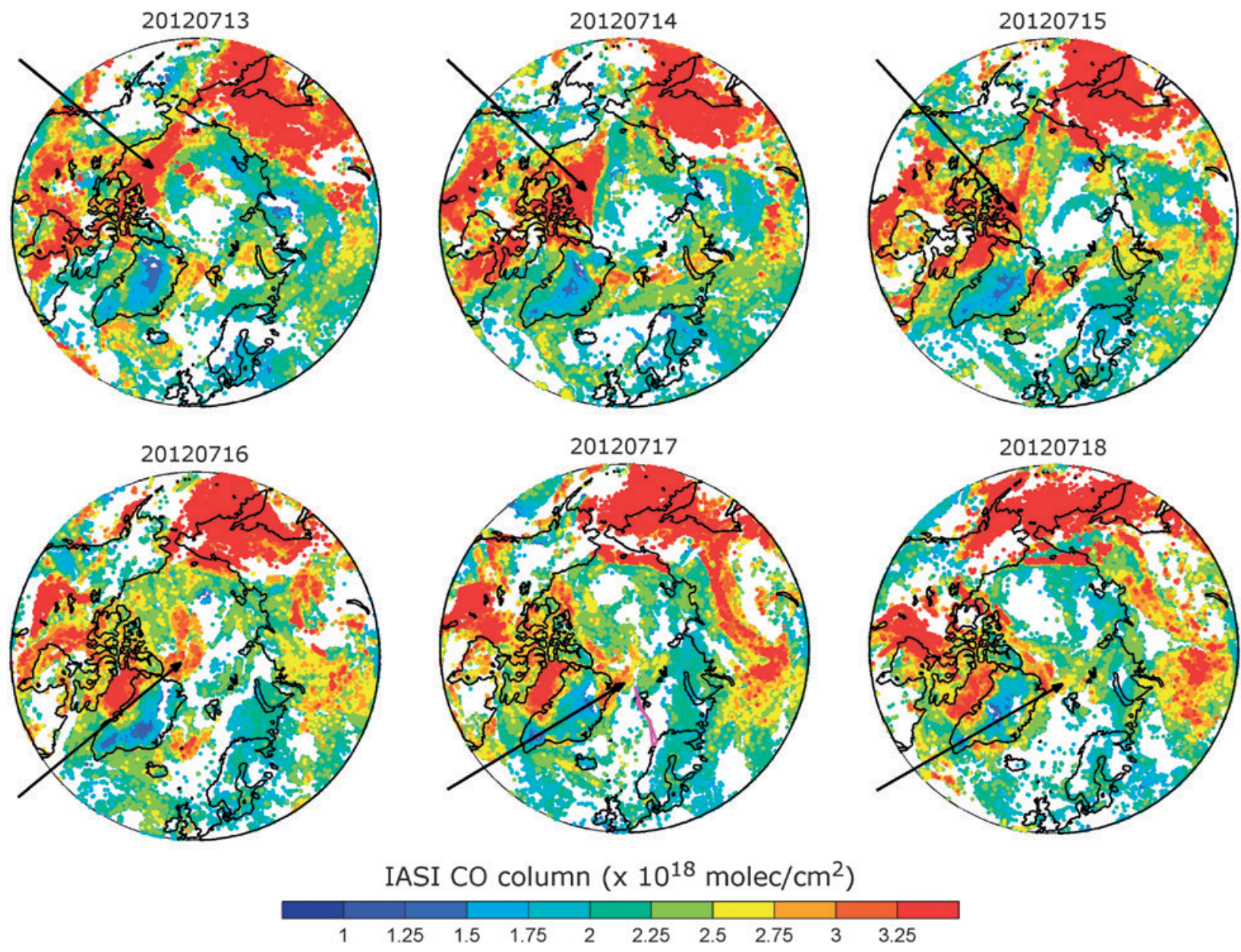

Fig. 10. IASI total column CO from I3 to $18 \mathrm{Jul} 2012$ shows significant $\mathrm{CO}$ enhancements in the Arctic. CO plumes are clearly seen on $13 \mathrm{Jul} 2012$ in the region over Siberia and in a large plume north of Canada that originated in Siberia. Enhanced CO plumes (highlighted using arrows) were transported across the Arctic toward Spitsbergen and subsequently measured by the Falcon on $17 \mathrm{Jul} 2012$ (flight track in magenta). White regions indicate presence of clouds, preventing CO retrievals.
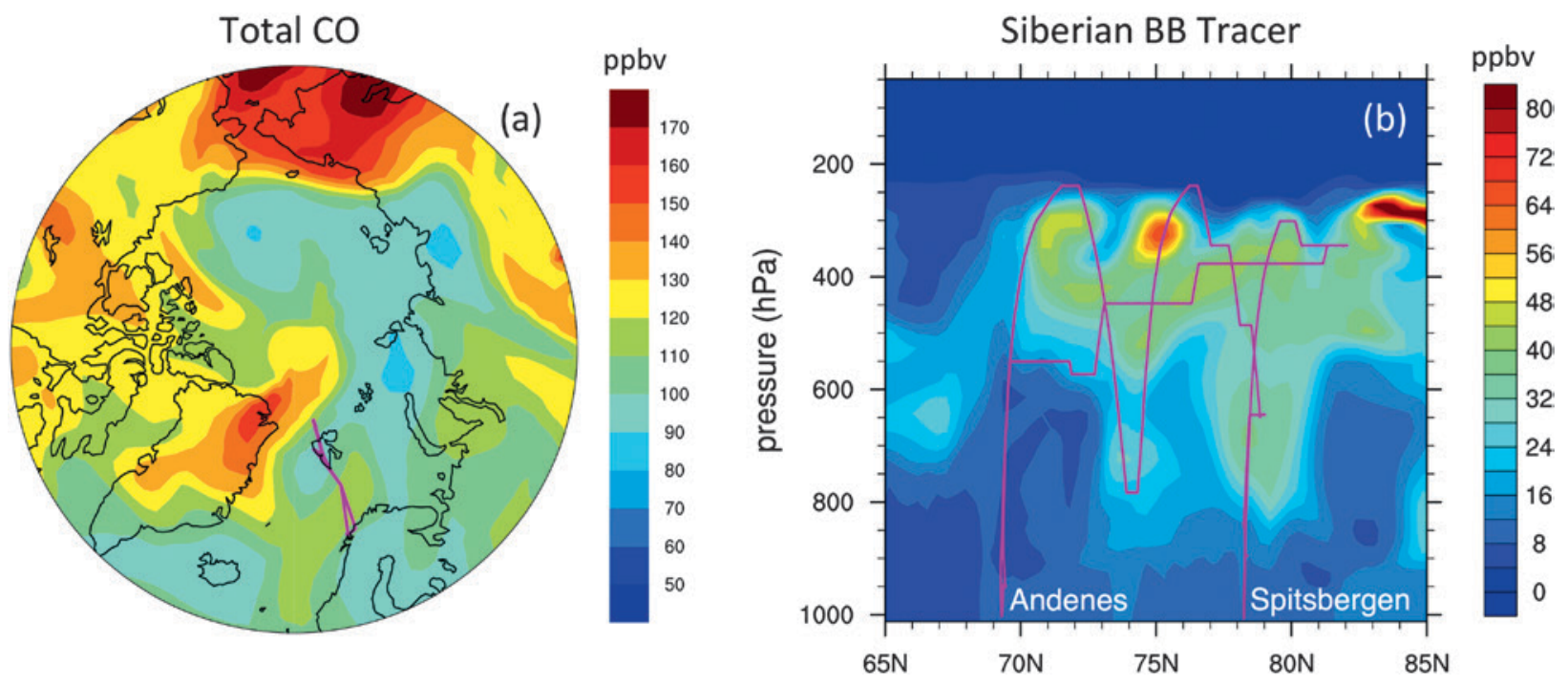

FIG. II. (a) Map of forecast total $\mathrm{CO}$ at $350 \mathrm{hPa}$ and (b) a cross section (longitude $=16^{\circ} \mathrm{E}$ ) for the Siberian biomass burning CO tracer from the MACC forecasts on 17 Jul 20I2. The forecasts indicate CO enhancements associated with Siberian BB plumes in the region north of Andenes and Spitsbergen. The Falcon flight tracks on I7 Jul 2012 are shown in magenta. 
during the first flight and then sampled the southern edge of a larger and more intense plume located farther north during the second flight before returning to Andenes. The vertical distributions of $\mathrm{CO}, \mathrm{rBC}$, and ozone measured during the flights on 17 July 2012 are shown in Fig. 12, which are compared to a vertical profile taken during the flight on 13 July 2012, which represents a more typical clean Arctic profile (when pollution does not influence trace gas and aerosol concentrations in the middle and upper troposphere).

We also compare the vertical profiles from 17 July 2012, with the average campaign profiles in Fig. 12. The profiles of $\mathrm{CO}, \mathrm{rBC}$, and ozone demonstrate that, during the campaign, transported pollution strongly influenced the middle and upper troposphere, even during flights that did not specifically focus on these plumes. The ACCESS measurements on 17 July and on average showed elevated $\mathrm{rBC}$ and $\mathrm{CO}$ concentrations due to the Siberian $\mathrm{BB}$ pollution, with median $\mathrm{rBC}$ values of 20-30 $\mathrm{ng} \mathrm{kg}^{-1}$, at altitudes between 6 and $9 \mathrm{~km}$. In comparison, Schwarz et al. (2013) reported that $\mathrm{rBC}$ values measured during the HIPPO campaign at similar latitudes (between $60^{\circ}$ and $80^{\circ} \mathrm{N}$ ), but in the remote Pacific region were usually below $10-20 \mathrm{ng} \mathrm{kg}^{-1}$, pointing for the need for improved representation of $\mathrm{BC}$ processing in models and the necessity to compare models with measurements in different Arctic regions.
SUMMARY AND OUTLOOK. The EU project ACCESS focuses on addressing challenges, risks, and opportunities related to the timely topic of Arctic change, including industrialization associated with shipping and hydrocarbon extraction activities. The measurements made during the ACCESS aircraft campaign included the first observations of emissions from Arctic offshore facilities and provided insights into the composition and atmospheric transformation of emissions released by emerging and increasing industrial activities in the Arctic. Measurements of short-lived climate forcers and their precursors $\left(\mathrm{O}_{3}, \mathrm{NO}_{x}, \mathrm{SO}_{2}\right.$, and aerosols including $\left.\mathrm{rBC}\right)$ were a specific focus of the ACCESS aircraft campaign. We found several distinct patterns in the chemical and aerosol composition from different emission sources, illustrated in Fig. 13. The vertical distributions of NO, $\mathrm{SO}_{2}$, and $\mathrm{CO}$ are shown for flights that include the most important pollution measurements $(11,12,13$, 17a, 17b, 19b, and 20 July). The measured fresh ship and oil and gas facility plumes are clearly visible in the Arctic boundary layer, with enhancements in NO and $\mathrm{SO}_{2}$ that are far above background levels (Figs. 13a,b). While production platforms and large vessels release the highest amounts of $\mathrm{NO}, \mathrm{SO}_{2}$ emissions are dominated by ships and shuttle/storage tankers operating in the region or as part of offshore oil and gas facilities.
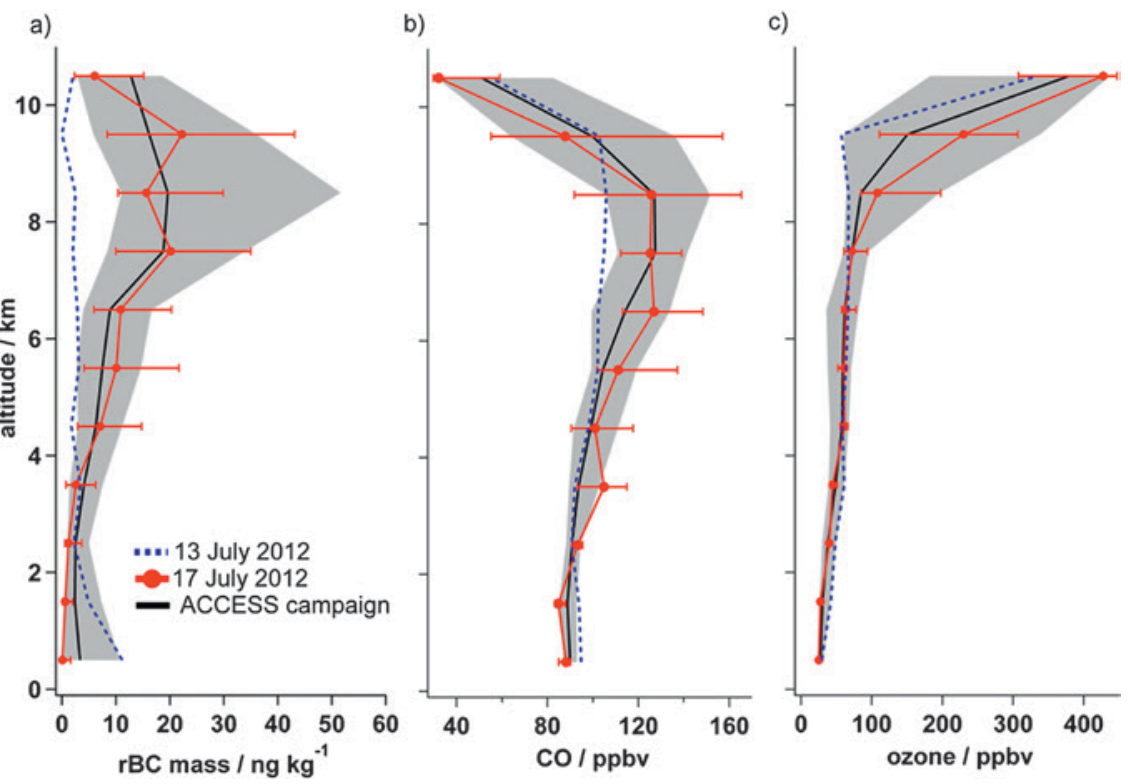

FIG. 12. Median vertical distributions of measured (a) rBC mass (equivalent diameter of approximately 80-510 nm), (b) carbon monoxide, and (c) ozone concentrations for the flights on 17 Jul 2012 that focused on Siberian BB pollution (red), a flight less impacted by Siberian BB pollution on I3 Jul 2012 (dashed blue), and for the entire campaign (black; I 2 flights from II to 22 Jul 20I2). The 20th and 80th percentiles are shown in gray for II-22 Jul 2012 and using error bars for 17 Jul 2012.
Kola Peninsula emissions measured on 13 July ( 1 day old) were enhanced in $\mathrm{SO}_{2}$ but contained lower values than measured in fresh plumes most likely owing to plume dilution and aging processes. In contrast, $\mathrm{CO}$ emissions from these pollution sources are negligible. On the other hand, the $\mathrm{CO}$ mixing ratios (Fig. 13c; see also Fig. 12b) in the middle and upper troposphere are enhanced in aged ( $~ 6-8$ days) pollution layers transported across the North Pole from Siberia and North America measured during multiple flights. A similar pollution transport pathway was already observed during the POLARCAT campaign (Roiger et al. 2011a; Sodemann et al. 2011) and 
a)

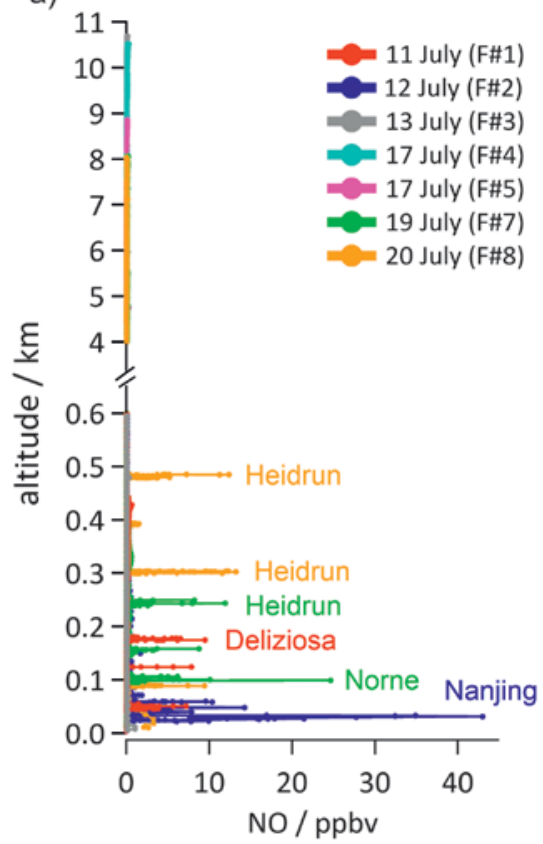

b)

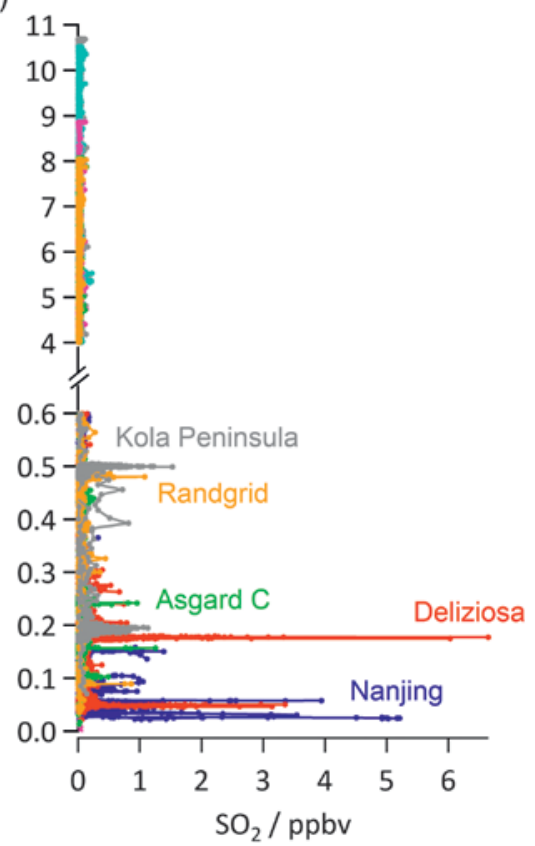

c)

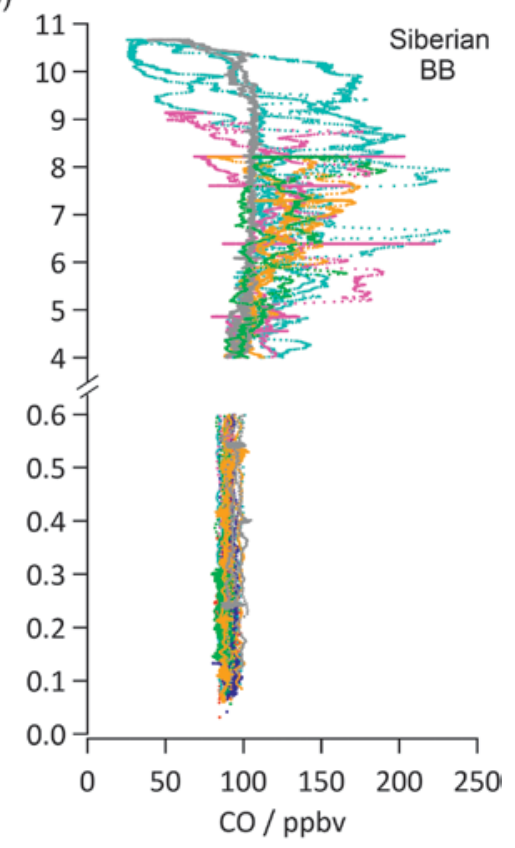

FIG. 13. Vertical profiles of (a) NO, (b) $\mathrm{SO}_{2}$, and (c) $\mathrm{CO}$ for selected flights that focused on shipping (II and 12 Jul), oil and gas extraction (19 and $20 \mathrm{Jul}$ ), Kola Peninsula (13 Jul), and Siberian BB (17 July) pollution. Specific plumes originating from ships, oil and gas platforms, and the Kola Peninsula are noted. Siberian biomass burning pollution was sampled on several days (17, 19, and $20 \mathrm{Jul})$. Please note the gap in the altitude axis between 0.6 and $4 \mathrm{~km}$.

is increasingly recognized as important for the Arctic region (e.g., Law et al. 2014).

In the future, more detailed studies will focus on quantification of emission fluxes from these sources using the measurements combined with plume dispersion modeling (A. Roiger 2015, unpublished manuscript; L. Marelle et al. 2015, unpublished manuscript). These emission estimates will be combined with regional chemical transport modeling to study plume evolution and the regional impacts of shipping and oil and gas extraction (e.g., L. Marelle et al. 2015, unpublished manuscript). The ACCESS campaign also resulted in detailed in situ measurements of the vertical BC distribution in the European Arctic in summer 2012. Future uses of the ACCESS campaign dataset will include assessing the impact of these biomass burning layers on the Arctic radiation budget.

CONCLUSIONS AND PERSPECTIVES. Although the Arctic sea ice has decreased dramatically during the last few decades (e.g., Overland and Wang 2013), the development of new industrial activities in the region is still uncertain. Arctic resource extraction, transit shipping, and other forms of resource exploitation depend on a sensitive and complex combination of future climatic, political, and economic developments. For example, the future of cross-polar transit shipping will depend both on access to navigable routes through the Arctic and on the availability of Arctic sea route transit permits and ice breakers to navigate these routes (www.arctic-lio .com/). The future of Arctic oil and gas extraction will be influenced by the price of gas and oil (making more expensive extraction in the Arctic feasible) as well as on geopolitical developments (e.g., regulations) that govern the Arctic region. However, in the long term, the expected increase in global energy consumption and increased open-water conditions are likely to make Arctic hydrocarbon extraction and shipping increasingly attractive.

The ACCESS aircraft campaign has provided one snapshot of current emissions from shipping and oil and gas facilities in one focus region. This is only the start of a process to characterize and understand the currently increasing industrial emissions in the Arctic. It is important to recognize that these emission patterns will change with future IMO regulations and with technology developments to operate in the harsh Arctic conditions. Follow-on studies to characterize local sources of air pollution in the Arctic are clearly needed. For example, comprehensive trace gas and aerosol measurements are required to further characterize pollutant emissions and processing. In particular, characterization of methane, 
hydrocarbons, and aerosol chemical composition will be important to understand the role of hydrocarbons in atmospheric chemistry and secondary aerosol formation. Finally, because of their importance in the Arctic radiation budget, measuring the vertical distribution of biomass burning and anthropogenic plumes in different parts of the Arctic must continue as a focus of future measurement campaigns.

ACKNOWLEDGMENTS. The research leading to these results received funding from the European Union under Grant Agreement 265863-ACCESS (www.access-eu .org) - within the Ocean of Tomorrow call of the European Commission Seventh Framework Programme. We thank the pilots, engineers, and scientists from the DLR flight department for their excellent support during the field campaign. We acknowledge the Statoil company for their cooperation during the ACCESS campaign period and for providing information on the operational modes of their facilities during the time of our measurements. We also thank the Wilson Ship management for reporting the current positions of their vessels during the campaign period. We thank ECMWF for providing access to data in the framework of the Support Tool for HALO Missions (SPDEHALO) special project. The scripts to run WRF-Chem operationally were provided by William Gustafson and Jerome Fast (Pacific Northwest National Laboratory) with support from the U.S. Department of Energy's Atmospheric System Research (ASR) program. The authors gratefully acknowledge David Browmich, Keith Hines, Sheng-Hung Wang, and Thomas Kassebaum for providing Polar-WRF output over Northern Hemisphere during the period of the ACCESS experiment. MACC II project is funded by the European Commission under the EU Seventh Research Framework Programme. IASI was developed and built under the responsibility of CNES and flies onboard the MetOp satellites as part of the Eumetsat Polar system. The authors also acknowledge Juliette Hadji-Lazaro (LATMOS), Pierre-François Coheur, Daniel Hurtmans (ULB), and the Ether French atmospheric database (http://ether.ipsl.jussieu .fr) for the IASI FORLI-CO data. B. Weinzierl, M. Rose, and F. Dahlkötter thank funding by the Helmholtz Association under Grant VH-NG-606 (Helmholtz-HochschulNachwuchsforschergruppe AerCARE). Finally, we thank two anonymous reviewers for their helpful comments.

\section{REFERENCES}

Andreae, M. O., and P. Merlet, 2001: Emission of trace gases and aerosols from biomass burning. Global Biogeochem. Cycles, 15, 955-966, doi:10.1029 /2000GB001382.

Baehr, J., H. Schlager, H. Ziereis, P. Stock, P. van Velthoven, R. Busen, J. Stroem, and U. Schumann, 2003: Aircraft observations of $\mathrm{NO}, \mathrm{NO}_{\mathrm{y}}, \mathrm{CO}$, and $\mathrm{O}_{3}$ in the upper troposphere from $60^{\circ} \mathrm{N}$ to $60^{\circ} \mathrm{S}$-Interhemispheric differences at midlatitudes. Geophys. Res. Lett., 30, 1598, doi:10.1029/2003GL016935.

Barrie, L., 1986: Arctic air pollution: An overview of current knowledge. Atmos. Environ., 20, 643-663, doi:10.1016/0004-6981(86)90180-0.

Bauduin, S., L. Clarisse, C. Clerbaux, D. Hurtmans, and P.-F. Coheur, 2014: IASI observations of sulfur dioxide $\left(\mathrm{SO}_{2}\right)$ in the boundary layer of Norilsk. J. Geophys. Res. Atmos., 119, 4253-4263, doi:10.1002/2013JD021405.

Beecken, J., J. Mellqvist, K. Salo, J. Ekholm, and J.-P. Jalkanen, 2014: Airborne emission measurements of $\mathrm{SO}_{2}, \mathrm{NO}_{\mathrm{x}}$ and particles from individual ships using a sniffer technique. Atmos. Meas. Tech., 7, 1957-1968, doi:10.5194/amt-7-1957-2014.

Benkovitz, C. M., and Coauthors, 1996: Global gridded inventories of anthropogenic emissions of sulfur and nitrogen. J. Geophys. Res., 101 (D22), 29239-29253, doi:10.1029/96JD00126.

Bond, T. C., and Coauthors, 2013: Bounding the role of black carbon in the climate system: A scientific assessment. J. Geophys. Res. Atmos., 118, 5380-5552, doi:10.1002/jgrd.50171.

Bourgeois, Q., and I. Bey, 2011: Pollution transport efficiency toward the Arctic: Sensitivity to aerosol scavenging and source regions. J. Geophys. Res., 116, D08213, doi:10.1029/2010JD015096.

Brioude, J., and Coauthors, 2013: The Lagrangian particle dispersion model FLEXPART-WRF version 3.1. Geosci. Model Dev., 6, 1889-1904, doi:10.5194 /gmd-6-1889-2013.

Brock, C. A., and Coauthors, 2011: Characteristics, sources, and transport of aerosols measured in spring 2008 during the aerosol, radiation, and cloud processes affecting Arctic Climate (ARCPAC) Project. Atmos. Chem. Phys., 11, 2423-2453, doi:10.5194 /acp-11-2423-2011.

Brooks, S. B., T. L. Crawford, and W. C. Oechel, 1997: Measurement of carbon dioxide emissions plumes from Prudhoe Bay, Alaska oil fields. J. Atmos. Chem., 27, 197-207, doi:10.1023/A:1005890318796.

Browse, J., K. S. Carslaw, S. R. Arnold, K. Pringle, and O. Boucher, 2012: The scavenging processes controlling the seasonal cycle in Arctic sulphate and black carbon aerosol. Atmos. Chem. Phys., 12, 6775-6798, doi:10.5194/acp-12-6775-2012.

Buffaloe, G. M., and Coauthors, 2014: Black carbon emissions from in-use ships: a California regional assessment. Atmos. Chem. Phys., 14, 1881-1896, doi:10.5194/acp-14-1881-2014.

Cai, Y., D. C. Montague, W. Mooiweer-Bryan, and T. Deshler, 2008: Performance characteristics of 
the ultra high sensitivity aerosol spectrometer for particles between 55 and $800 \mathrm{~nm}$ : Laboratory and field studies. J. Aerosol Sci., 39, 759-769, doi:10.1016/j .jaerosci.2008.04.007.

Cappa, C. D., and Coauthors, 2014: A case study into the measurement of ship emissions from plume intercepts of the NOAA ship Miller Freeman. Atmos. Chem. Phys., 14, 1337-1352, doi:10.5194/acp-14 $-1337-2014$.

Cariolle, D., D. Caro, R. Paoli, D. A. Hauglustaine, B. Cuénot, A. Cozic, and R. Paugam, 2009: Parameterization of plume chemistry into large-scale atmospheric models: Application to aircraft $\mathrm{NO}_{\mathrm{x}}$ emissions. J. Geophys. Res., 114, D19302, doi:10.1029 /2009JD011873.

Chen, G., and Coauthors, 2005: An investigation of the chemistry of ship emission plumes during ITCT 2002. J. Geophys. Res., 110, D10S90, doi:10.1029/2004JD005236.

Corbett, J. J., D. A. Lack, J. J. Winebrake, S. Harder, J. A. Silberman, and M. Gold, 2010: Arctic shipping emissions inventories and future scenarios. Atmos. Chem. Phys., 10, 9689-9704, doi:10.5194/acp-10-9689-2010.

Dahlkötter, F., and Coauthors, 2014: The Pagami Creek smoke plume after long-range transport to the upper troposphere over Europe-Aerosol properties and black carbon mixing state. Atmos. Chem. Phys., 14, 6111-6137, doi:10.5194/acp-14-6111-2014.

Dalsøren, S. B., B. H. Samset, G. Myhre, J. J. Corbett, R. Minjares, D. Lack, and J. S. Fuglestvedt, 2013: Environmental impacts of shipping in 2030 with a particular focus on the Arctic region. Atmos. Chem. Phys., 13, 1941-1955, doi:10.5194/acp-13-1941-2013.

Diesch, J.-M., F. Drewnick, T. Klimach, and S. Borrmann, 2013: Investigation of gaseous and particulate emissions from various marine vessel types measured on the banks of the Elbe in Northern Germany. Atmos. Chem. Phys., 13, 3603-3618, doi:10.5194 /acp-13-3603-2013.

Draxler, R. R., and G. D. Hess, 1998: An overview of the HYSPLIT_4 modeling system of trajectories, dispersion, and deposition. Aust. Meteor. Mag., 47, 295-308.

Dye, J. E., and D. Baumgardner, 1984: Evaluation of the forward scattering spectrometer probe. Part I: Electronic and optical studies. J. Atmos. Oceanic Technol., 1, 329-344, doi:10.1175/1520 -0426(1984)0012.0.CO;2.

Eckhardt, S., O. Hermansen, H. Grythe, M. Fiebig, K. Stebel, M. Cassiani, A. Baecklund, and A. Stohl, 2013: The influence of cruise ship emissions on air pollution in Svalbard-A harbinger of a more polluted Arctic? Atmos. Chem. Phys., 13, 8401-8409, doi:10.5194/acp-13-8401-2013.
Fast, J. D., W. I. Gustafson Jr., R. C. Easter, R. A. Zaveri, J. C. Barnard, E. G. Chapman, G. A. Grell, and S. E. Peckham, 2006: Evolution of ozone, particulates, and aerosol direct radiative forcing in the vicinity of Houston using a fully-coupled meteorologychemistry-aerosol model. J. Geophys. Res., 111, D21305, doi:10.1029/2005JD006721.

Fiebig, M., 2001: Das troposphärische Aerosol in mittleren Breiten-Mikrophysik, Optik und Klimaantrieb am Beispiel der Feldstudie LACE 98. Ph.D. thesis, Ludwig-Maximilians Universität München, $244 \mathrm{pp}$.

Flanner, M. G., C. S. Zender, J. T. Randerson, and P. J. Rasch, 2007: Present-day climate forcing and response from black carbon in snow. J. Geophys. Res., 112, D11202, doi:10.1029/2006JD008003.

Gautier, D. L., and Coauthors, 2009: Assessment of undiscovered oil and gas in the Arctic. Science, 324, 1175-1179, doi:10.1126/science.1169467.

George, M., and Coauthors, 2009: Carbon monoxide distributions from the IASI/METOP mission: Evaluation with other space-borne remote sensors. Atmos. Chem. Phys., 9, 8317-8330, doi:10.5194/acp -9-8317-2009.

Gerbig, C., S. Schmitgen, D. Kley, A. Volz-Thomas, K. Dewey, and D. Haaks, 1999: An improved fastresponse vacuum-UV resonance fluorescence $\mathrm{CO}$ instrument. J. Geophys. Res., 104 (D1), 1699-1704, doi:10.1029/1998JD100031.

Grell, G. A., S. E. Peckham, R. Schmitz, S. A. McKeen, G. Frost, W. C. Skamarock, and B. Eder, 2005: Fully coupled "online" chemistry within the WRF model. Atmos. Environ., 39, 6957-6976, doi:10.1016/j .atmosenv.2005.04.027.

Heim, M., B. J. Mullins, H. Umhauer, and G. Kasper, 2008: Performance evaluation of three optical particle counters with an efficient "multimodal" calibration method. J. Aerosol Sci., 39, 1019-1031, doi:10.1016/j.jaerosci.2008.07.006.

Hines, K. M., and D. H. Bromwich, 2008: Development and testing of polar WRF. Part I: Greenland ice sheet meteorology. Mon. Wea. Rev., 136, 1971-1989, doi:10.1175/2007MWR2112.1.

Hobbs, P. V., and Coauthors, 2000: Emissions from ships with respect to their effects on clouds. J. Atmos. Sci., 57, 2570-2590, doi:10.1175/1520 $-0469(2000) 0572.0 . \mathrm{CO} ; 2$.

Hollingsworth, A., and Coauthors, 2008: Toward a monitoring and forecasting system for atmospheric composition: The GEMS Project. Bull. Amer. Meteor. Soc., 89, 1147-1164, doi:10.1175/2008BAMS2355.1.

Hoppel, W. A., G. M. Frick, and R. E. Larson, 1986: Effect of nonprecipitating clouds on the aerosol 
size distribution in the marine boundary layer. Geophys. Res. Lett., 13, 125-128, doi:10.1029 /GL013i002p00125.

Huntrieser, H., and Coauthors, 2005: Intercontinental air pollution transport from North America to Europe: Experimental evidence from airborne measurements and surface observations. J. Geophys. Res., 110, D01305, doi:10.1029/2004JD005045.

Hurtmans, D., and Coauthors, 2012: FORLI radiative transfer and retrieval code for IASI. J. Quant. Spectrosc. Radiat. Transfer, 113, 1391-1408, doi:10.1016 /j.jqsrt.2012.02.036.

Huszar, P., D. Cariolle, R. Paoli, T. Halenka, M. Belda, H. Schlager, J. Miksovsky, and P. Pisoft, 2010: Modeling the regional impact of ship emissions on $\mathrm{NO}_{\mathrm{x}}$ and ozone levels over the Eastern Atlantic and Western Europe using ship plume parameterization. Atmos. Chem. Phys., 10, 6645-6660, doi:10.5194/acp-10 $-6645-2010$.

Jacob, D. J., and Coauthors, 2010: The Arctic Research of the Composition of the Troposphere from Aircraft and Satellites (ARCTAS) mission: Design, execution, and first results. Atmos. Chem. Phys., 10, 5191-5212, doi:10.5194/acp-10-5191-2010.

Jaffe, D. A., R. E. Honrath, D. Furness, T. J. Conway, E. Dlugokencky, and L. P. Steele, 1995: A determination of the $\mathrm{CH}_{4}, \mathrm{NO}_{x}$ and $\mathrm{CO}_{2}$ emissions from the Prudhoe Bay, Alaska oil development. J. Atmos. Chem., 20, 213-227, doi:10.1007/BF00694494.

Jalkanen, J.-P., L. Johansson, J. Kukkonen, A. Brink, J. Kalli, and T. Stipa, 2012: Extension of an assessment model of ship traffic exhaust emissions for particulate matter and carbon monoxide. Atmos. Chem. Phys., 12, 2641-2659, doi:10.5194/acp-12-2641-2012.

Jonsson, Å. M., J. Westerlund, and M. Hallquist, 2011: Size-resolved particle emission factors for individual ships. Geophys. Res. Lett., 38, L13809, doi:10.1029/2011GL047672.

Kalnay, E., and Coauthors, 1996: The NCEP/NCAR 40-Year Reanalysis Project. Bull. Amer. Meteor. Soc., 77, 437-471, doi:10.1175/1520-0477(1996)0772.0 .CO;2.

Karion, A., and Coauthors, 2013: Methane emissions estimate from airborne measurements over a western United States natural gas field. Geophys. Res. Lett., 40, 4393-4397, doi:10.1002/grl.50811.

Kasischke, E. S., and M. R. Turetsky, 2006: Recent changes in the fire regime across the North American boreal region-Spatial and temporal patterns of burning across Canada and Alaska. Geophys. Res. Lett., 33, L09703, doi:10.1029/2006GL025677.

Kelly, R., M. L. Chipman, P. E. Higuera, I. Stefanova, L. B. Brubaker, and F. S. Hu, 2013: Recent burning of boreal forests exceeds fire regime limits of the past 10,000 years. Proc. Natl. Acad. Sci. USA, 110, 13055-13 060, doi:10.1073/pnas.1305069110.

Kim, J., and Coauthors, 2013: Airborne measurements of emissions from oil and gas exploration and production activities in the Norwegian Sea. 2013 Fall Meeting, San Francisco, CA, Amer. Geophys. Union, Abstract A41F-0117.

Kyrö, E.-M., and Coauthors, 2014: Trends in new particle formation in eastern Lapland, Finland: Effect of decreasing sulfur emissions from Kola Peninsula. Atmos. Chem. Phys., 14, 4383-4396, doi:10.5194 /acp-14-4383-2014.

Lack, D. A., and J. J. Corbett, 2012: Black carbon from ships: A review of the effects of ship speed, fuel quality and exhaust gas scrubbing. Atmos. Chem. Phys., 12, 3985-4000, doi:10.5194/acp-12-3985-2012.

— - and Coauthors, 2009: Particulate emissions from commercial shipping: Chemical, physical, and optical properties. J. Geophys. Res., 114, D00F04, doi:10.1029/2008JD011300.

— , and Coauthors, 2011: Impact of fuel quality regulation and speed reductions on shipping emissions: Implications for climate and air quality. Environ. Sci. Technol., 45, 9052-9060, doi:10.1021 les2013424.

Law, K. S., and A. Stohl, 2007: Arctic air pollution: Origins and impacts. Science, 315, 1537-1540, doi:10.1126/science.1137695.

—, and Coauthors, 2014: Arctic air pollution: New insights from POLARCAT-IPY. Bull. Amer. Meteor. Soc., 95, 1873-1895, doi:10.1175/BAMS -D-13-00017.1.

Lee, Y. H., and Coauthors, 2013: Evaluation of preindustrial to present-day black carbon and its albedo forcing from Atmospheric Chemistry and Climate Model Intercomparison Project (ACCMIP). Atmos. Chem. Phys., 13, 2607-2634, doi:10.5194/acp-13-2607-2013.

Liu, M., and J. Kronbak, 2010: The potential economic viability of using the Northern Sea Route (NSR) as an alternative route between Asia and Europe. J. Transp. Geogr., 18, 434-444, doi:10.1016/j.jtrangeo .2009.08.004.

Liu, P. S. K., W. R. Leaitch, J. W. Strapp, and M. A. Wasey, 1992: Response of particle measuring systems airborne ASASP and PCASP to $\mathrm{NaCl}$ and latex particles. Aerosol Sci. Technol., 16, 83-95, doi:10.1080 /02786829208959539.

Liu, X., and Coauthors, 2012: Toward a minimal representation of aerosols in climate models: Description and evaluation in the Community Atmosphere Model CAM5. Geosci. Model Dev., 5, 709-739, doi:10.5194/gmd-5-709-2012. 
Moldanová, J., and Coauthors, 2013: Physical and chemical characterisation of PM emissions from two ships operating in European Emission Control Areas. Atmos. Meas. Tech., 6, 3577-3596, doi:10.5194 lamt-6-3577-2013.

Murray, J. L., 1998: Physical/geographical characteristics of the Arctic. AMAP assessment report: Arctic pollution issues, Arctic Monitoring and Assessment Programme Rep., 9-24.

Ødemark, K., S. B. Dalsøren, B. H. Samset, T. K. Berntsen, J. S. Fuglestvedt, and G. Myhre, 2012: Short-lived climate forcers from current shipping and petroleum activities in the Arctic. Atmos. Chem. Phys., 12, 1979-1993, doi:10.5194/acp-12-1979-2012.

Overland, J. E., and M. Wang, 2013: When will the summer Arctic be nearly sea ice free? Geophys. Res. Lett., 40, 2097-2101, doi:10.1002/grl.50316.

Paris, J-D., and Coauthors, 2008: The YAK-AEROSIB transcontinental aircraft campaigns: New insights on the transport of $\mathrm{CO}_{2}, \mathrm{CO}$ and $\mathrm{O}_{3}$ across Siberia. Tellus B, 60, 551-568, doi:10.1111/j.1600-0889.2008.00369.x.

Peters, G. P., T. B. Nilssen, L. Lindholt, M. S. Eide, S. Glomsrød, L. I. Eide, and J. S. Fuglestvedt, 2011: Future emissions from shipping and petroleum activities in the Arctic. Atmos. Chem. Phys., 11, 5305-5320, doi:10.5194/acp-11-5305-2011.

Pétron, G., and Coauthors, 2014: A new look at methane and nonmethane hydrocarbon emissions from oil and natural gas operations in the Colorado DenverJulesburg Basin. J. Geophys. Res., 119, 6836-6852, doi:10.1002/2013JD021272.

Petzold, A., and Coauthors, 2007: Perturbation of the European free troposphere aerosol by North American forest fire plumes during the ICARTTITOP experiment in summer 2004. Atmos. Chem. Phys., 7, 5105-5127, doi:10.5194/acp-7-5105-2007.

— J. Jasselbach, P. Lauer, R. Baumann, K. Franke, C. Gurk, H. Schlager, and E. Weingartner, 2008: Experimental studies on particle emissions from cruising ship, their characteristic properties, transformation and atmospheric lifetime in the marine boundary layer. Atmos. Chem. Phys., 8, 2387-2403, doi:10.5194 lacp-8-2387-2008.

— - and Coauthors, 2013: Recommendations for reporting "black carbon" measurements. Atmos. Chem. Phys., 13, 8365-8379, doi:10.5194/acp-13-8365-2013.

Pollack, I. B., B. M. Lerner, and T. B. Ryerson, 2010: Evaluation of ultraviolet light-emitting diodes for detection of atmospheric NO2 by photolysisChemiluminescence. J. Atmos. Chem., 65, 111-125, doi:10.1007/s10874-011-9184-3.

Ponomarev, E. I., 2013: Radiative power of wildfires in Siberia on the basis of TERRA/Modis imagery processing. Folia For. Pol., 55A, 102-110, doi:10.2478 /ffp-2013-00011.

Prank, M., M. Sofiev, H. A. C. Denier van der Gon, M. Kaasik, T. M. Ruuskanen, and J. Kukkonen, 2010: A refinement of the emission data for Kola Peninsula based on inverse dispersion modelling. Atmos. Chem. Phys., 10, 10849-10865, doi:10.5194/acp-10-10849-2010.

Quinn, P. K., G. Shaw, E. Andrews, E. G. Dutton, T. Ruoho-Airola, and S. L. Gong, 2007: Arctic haze: Current trends and knowledge gaps. Tellus, 59B, 99-114, doi:10.1111/j.1600-0889.2006.00238.x.

— - and Coauthors, 2008: Short-lived pollutants in the Arctic: Their climate impact and possible mitigation strategies. Atmos. Chem. Phys., 8, 1723-1735, doi:10.5194/acp-8-1723-2008.

Rautenhaus, M., G. Bauer, and A. Dörnbrack, 2012: A web service based tool to plan atmospheric research flights. Geosci. Model Dev., 5, 55-71, doi:10.5194 /gmd-5-55-2012.

Roiger, A., and Coauthors, 2011a: In-situ observation of Asian pollution transported into the Arctic lowermost stratosphere. Atmos. Chem. Phys., 11, 102975-102994, doi:10.5194/acp-11-10975-2011.

_ , H. Aufmhoff, P. Stock, F. Arnold, and H. Schlager, 2011b: An aircraft-borne chemical ionization-Ion trap mass spectrometer (CI-ITMS) for fast PAN and PPN measurements. Atmos. Meas. Tech., 4, 173-188, doi:10.5194/amt-4-173-2011.

Sand, M., T. K. Berntsen, Ø. Seland, and J. E. Kristjánsson, 2013: Arctic surface temperature change to emissions of black carbon within Arctic or midlatitudes. J. Geophys. Res., 118, 7788-7798, doi:10.1002 /jgrd.50613.

Schwarz, J. P., and Coauthors, 2006: Single-particle measurements of midlatitude black carbon and light-scattering aerosols from the boundary layer to the lower stratosphere. J. Geophys. Res., 111, D16207, doi:10.1029/2006JD007076.

— , and Coauthors, 2013: Global-scale seasonally resolved black carbon vertical profiles over the Pacific. Geophys. Res. Lett., 40, 5542-5547, doi:10.1002/2013GL057775.

Shindell, D. T., and Coauthors, 2008: A multi-model assessment of pollution transport to the Arctic. Atmos. Chem. Phys., 8, 5353-5372, doi:10.5194/acp -8-5353-2008.

Singh, H., and Coauthors, 2010: Pollution influences on atmospheric composition and chemistry at high northern latitudes: Boreal and California forest fire emissions. Atmos. Environ., 44, 4553-4564, doi:10.1016/j.atmosenv.2010.08.026.

Smith, L. C., and S. R. Stephenson, 2013: New TransArctic shipping routes navigable by midcentury. Proc. 
Natl. Acad. Sci. USA, 110, E1191-E1195, doi:10.1073 /pnas.1214212110.

Sodemann, H., and Coauthors, 2011: Episodes of crosspolar transport in the Arctic troposphere during July 2008 as seen from models, satellite, and aircraft observations. Atmos. Chem. Phys., 11, 3631-3651, doi:10.5194/acp-11-3631-2011.

Song, C. H., G. Chen, S. R. Hanna, J. Crawford, and D. D. Davis, 2003: Dispersion and chemical evolution of ship plumes in the marine boundary layer: Investigation of $\mathrm{O}_{3} / \mathrm{NO}_{y} / \mathrm{HO}_{x}$ chemistry. J. Geophys. Res., 108, 4143, doi:10.1029/2002JD002216.

Speidel, M., R. Nau, F. Arnold, H. Schlager, and A. Stohl, 2007: Sulfur dioxide measurements in the lower, middle and upper troposphere: Deployment of an aircraft-based chemical ionization mass spectrometer with permanent in-flight calibration. Atmos. Environ., 41, 2427-2437, doi:10.1016/j. atmosenv.2006.07.047.

Stein, C., F. Schröder, and A. Petzold, 2001: The condensation particle size analyzer: A new instrument for the measurement of ultrafine aerosol size distributions. J. Aerosol Sci., 32, S381-S382.

Stocker, T. F., and Coauthors, Eds., 2014: Climate Change 2013: The Physical Science Basis. Cambridge University Press, 1535 pp.

Stocks, B. J., and Coauthors, 1998: Climate change and forest fire potential in Russian and Canadian boreal forests. Climatic Change, 38, 1-13, doi:10.1023/A :1005306001055.

Stohl, A., 2006: Characteristics of atmospheric transport into the Arctic troposphere. J. Geophys. Res., 111, D11306, doi:10.1029/2005JD006888.

—, C. Forster, H. Huntrieser, H. Mannstein, W. W. McMillan, A. Petzold, H. Schlager, and B. Weinzierl, 2007: Aircraft measurements over Europe of an air pollution plume from Southeast Asia-Aerosol and chemical characterization. Atmos. Chem. Phys., 7, 913-937, doi:10.5194/acp-7-913-2007.

—, Z. Klimont, S. Eckhardt, K. Kupiainen, V. P. Shevchenko, V. M. Kopeikin, and A. N. Novigatsky, 2013: Black carbon in the Arctic: The underestimated role of gas flaring and residential combustion emissions. Atmos. Chem. Phys., 13, 8833-8855, doi:10.5194/acp-13-8833-2013.

Thomas, J. L., and Coauthors, 2013: Pollution transport from North America to Greenland during summer 2008. Atmos. Chem. Phys., 13, 3825-3848, doi:10.5194/acp-13-3825-2013.

Vinken, G. C. M., K. F. Boersma, D. J. Jacob, and E. W. Meijer, 2011: Accounting for non-linear chemistry of ship plumes in the GEOS-Chem global chemistry transport model. Atmos. Chem. Phys., 11, $11707-$ 11 722, doi:10.5194/acp-11-11707-2011.

Virkkula, A., R. E. Hillamo, V. M. Kerminen, and A. Stohl, 1998: The influence of Kola Peninsula, continental European and marine sources on the number concentrations and scattering coefficients of the atmospheric aerosol in Finnish Lapland. Boreal Environ. Res., 2, 317-336.

—, N. C. Ahlquist, D. S. Covert, W. P. Arnott, P. J. Sheridan, P. K. Quinn, and D. J. Coffman, 2005: Modification, calibration and a field test of an instrument for measuring light absorption by particles. Aerosol Sci. Technol., 39, 68-83, doi:10.1080 /027868290901963.

Walter, D., K. P. Heue, A. Rauthe-Schöch, C. A. M. Brenninkmeijer, L. N. Lamsal, N. A. Krotkov, and U. Platt, 2012: Flux calculation using CARIBIC DOAS aircraft measurements: $\mathrm{SO}_{2}$ emission of Norilsk. J. Geophys. Res., 117, D11305, doi:10.1029/2011JD017335. Warneke, C., and Coauthors, 2009: Biomass burning in Siberia and Kazakhstan as an important source for haze over the Alaskan Arctic in April 2008. Geophys. Res. Lett., 36, L02813, doi:10.1029/2008GL036194.

Weinzierl, B., and Coauthors, 2011: Microphysical and optical properties of dust and tropical biomass burning aerosol layers in the Cape Verde region-An overview of the airborne in-situ and lidar measurements during SAMUM-2. Tellus, 63, 589-618, doi:10.1111/j.1600-0889.2011.00566.x.

Wild, O., M. Prather, and H. Akimoto, 2001: Indirect long-term global radiative cooling from $\mathrm{NO}_{\mathrm{x}}$ emissions. Geophys. Res. Lett., 28, 1719-1722, doi:10.1029/2000GL012573.

Williams, E. J., B. M. Lerner, P. C. Murphy, S. C. Herndon, and M. S. Zahniser, 2009: Emissions of $\mathrm{NO}_{\mathrm{x}}, \mathrm{SO}_{2}, \mathrm{CO}$, and $\mathrm{HCHO}$ from commercial marine shipping during Texas Air Quality Study (TexAQS) 2006. J. Geophys. Res., 114, D21306, doi:10.1029/2009JD012094.

Ziereis, H., and Coauthors, 2004: Uptake of reactive nitrogen on cirrus cloud particles during INCA. Geophys. Res. Lett., 31, L05115, doi:10.1029/2003GL018794. 